\title{
Molecular pathological epidemiology of epigenetics: emerging integrative science to analyze environment, host, and disease
}

Shuji Ogino ${ }^{1,2,3}$, Paul Lochhead ${ }^{3,4}$, Andrew T Chan ${ }^{5,6}$, Reiko Nishihara ${ }^{3}$, Eunyoung Cho $^{6}$, Brian M Wolpin ${ }^{3}$, Jeffrey A Meyerhardt ${ }^{3}$, Alexander Meissner ${ }^{7}$, Eva S Schernhammer ${ }^{2,6}$, Charles S Fuchs ${ }^{3,6}$ and Edward Giovannucci ${ }^{2,6,8}$

${ }^{1}$ Department of Pathology, Brigham and Women's Hospital, and Harvard Medical School, Boston, MA, USA; ${ }^{2}$ Department of Epidemiology, Harvard School of Public Health, Boston, MA, USA; ${ }^{3}$ Department of Medical Oncology, Dana-Farber Cancer Institute, Boston, MA, USA ${ }^{4}$ Institute of Medical Sciences, University of Aberdeen, Aberdeen, UK; ${ }^{5}$ Division of Gastroenterology, Massachusetts General Hospital, Boston, MA, USA; ${ }^{6}$ Channing Division of Network Medicine, Department of Medicine, Brigham and Women's Hospital, and Harvard Medical School, Boston, MA, USA; ${ }^{7}$ Broad Institute of MIT and Harvard University, Cambridge, MA, USA and ${ }^{8}$ Department of Nutrition, Harvard School of Public Health, Boston, MA, USA

Epigenetics acts as an interface between environmental/exogenous factors, cellular responses, and pathological processes. Aberrant epigenetic signatures are a hallmark of complex multifactorial diseases (including neoplasms and malignancies such as leukemias, lymphomas, sarcomas, and breast, lung, prostate, liver, and colorectal cancers). Epigenetic signatures (DNA methylation, mRNA and microRNA expression, etc) may serve as biomarkers for risk stratification, early detection, and disease classification, as well as targets for therapy and chemoprevention. In particular, DNA methylation assays are widely applied to formalin-fixed, paraffin-embedded archival tissue specimens as clinical pathology tests. To better understand the interplay between etiological factors, cellular molecular characteristics, and disease evolution, the field of 'molecular pathological epidemiology (MPE)' has emerged as an interdisciplinary integration of 'molecular pathology' and 'epidemiology'. In contrast to traditional epidemiological research including genome-wide association studies (GWAS), MPE is founded on the unique disease principle, that is, each disease process results from unique profiles of exposomes, epigenomes, transcriptomes, proteomes, metabolomes, microbiomes, and interactomes in relation to the macroenvironment and tissue microenvironment. MPE may represent a logical evolution of GWAS, termed 'GWAS-MPE approach'. Although epigenome-wide association study attracts increasing attention, currently, it has a fundamental problem in that each cell within one individual has a unique, timevarying epigenome. Having a similar conceptual framework to systems biology, the holistic MPE approach enables us to link potential etiological factors to specific molecular pathology, and gain novel pathogenic insights on causality. The widespread application of epigenome (eg, methylome) analyses will enhance our understanding of disease heterogeneity, epigenotypes (CpG island methylator phenotype, LINE-1 (long interspersed nucleotide element-1; also called long interspersed nuclear element-1; long interspersed element1; L1) hypomethylation, etc), and host-disease interactions. In this article, we illustrate increasing contribution of modern pathology to broader public health sciences, which attests pivotal roles of pathologists in the new integrated MPE science towards our ultimate goal of personalized medicine and prevention.

Modern Pathology (2013) 26, 465-484; doi:10.1038/modpathol.2012.214; published online 11 January 2013

Keywords: CIMP; genetics; hypermethylation; molecular pathological epidemiology; omics; personalized therapy; unique tumor principle

Correspondence: Dr S Ogino, MD, PhD, MS (Epidemiology), Department of Epidemiology, Harvard School of Public Health, Department of Pathology, Brigham and Women's Hospital, 450 Brookline Avenue, Room JF-215C, Boston, MA 02215, USA. E-mail: shuji_ogino@dfci.harvard.edu

Received 12 September 2012; revised 5 November 2012; accepted 8 November 2012; published online 11 January 2013
Epigenetic mechanisms constitute an essential mode of gene regulation and act as an interface between environmental exposures, cellular response, and pathological processes. DNA methylation level and its location constitute important gene regulatory mechanisms. ${ }^{1-4}$ Abnormal epigenetic 
marks, including DNA methylation alterations, are a hallmark of most human diseases. Importantly, epigenetic modifications are reversible, and represent potential targets for disease prevention and therapy. ${ }^{2-6}$ There are other epigenetic mechanisms of gene regulations, such as noncoding RNA including microRNA. ${ }^{7-13}$ Gene expression levels are consequences of epigenetic regulation; however, there exists a challenge in accurate quantification of transcript levels in archival tissues. ${ }^{14}$ As most studies, which have examined host exposures and epigenetic alterations, utilized DNA methylation as biomarkers, our discussion on previous data mostly addresses DNA methylation.

Accumulating evidence suggests that epigenetic aberrations induced by environmental, dietary, lifestyle, and microbial factors contribute to specific disease processes. ${ }^{15-22}$ To examine the complex relationships between etiological factors, molecular alterations, and disease evolution, 'molecular pathology' and 'epidemiology' have recently become integrated, generating the interdisciplinary field of 'molecular pathological epidemiology (MPE)'. ${ }^{21-23}$

As clinical molecular pathology testing is becoming more and more common, we anticipate that molecular pathology data can be acumulated into disease registries around the world. This enables MPE to become routine epidemiology and pathology research practice. Thus, a role of pathologists as educators for epidemiologists will increase. We must emphasize pivotal roles of modern pathologists in broader transdisciplinary biomedical and public health sciences, as well as in clinical decision-making process.

In this article, we provide an overview of the MPE paradigm, and proceed to illustrate the contribution made by epigenetic research. While we exploit MPE data on neoplastic disorders, MPE approaches and paradigms can conceptually extend to the study of non-neoplastic diseases.

\section{Tissue and Cellular Heterogeneity: Challenges in Epigenetic Research}

In many non-neoplastic, non-hematological, nondermatological diseases, access to diseased cells is limited by current technologies. ${ }^{24-27}$ Even if tissues affected by a non-neoplastic disease (eg, inflamed liver) can be obtained, those tissues consist of many different cell types with varying epigenomes. Therefore, epigenetic analysis of non-neoplastic diseases faces a fundamental challenge of heterogeneity in tissue, cells, and epigenomes, which is often overlooked or underestimated in research studies and proposals (not limited to MPE).

Notably, the epigenome differs between specific cell types (even within a single organ). In a single cell, the epigenome changes, as the cell responds to the microenvironmental changes over time. A single organ (or tissue) consists of numerous cell types with different epigenomes.

A particular human disease process is caused by dysfunction of a specific cell type, or multiple cell types (in one organ or across multiple organ systems). Thus, the optimal approach is to analyze molecular changes in the afflicted cell types specific to the disease process. To study a psychiatric or neuronal disease, it would be best to analyze disordered neurons (within the context of local microenvironment), rather than blood leukocytes or brain tissue as a mixture of different cell types. ${ }^{28,29,30}$ Clearly, we must analyze specific cell types in each tissue in a particular microenvironmental and disease context, using techniques such as laser capture microdissection and flow cytometry. ${ }^{31,32}$

Epigenomic differences between cell types may be present in a small part of the genome (with overall similar epigenomic status); however, those minor differences are critical in specific cell-type function and disease pathogenesis, and unlikely inferred from examining the epigenomes of different cell types. Although many epigenetic studies rely on blood leukocytes as a surrogate for alterations in other diseased cell types, ${ }^{24-27,29,30-36}$ there is very little evidence supporting the validity of inferring epigenetic mechanisms of nonhematological disorders from epigenetic analysis of blood leukocytes.

In contrast to non-neoplastic diseases, neoplastic diseases are characterized by uncontrolled cellular proliferation, which can provide abundant amounts of diseased cells for epigenetic analyses. We nevertheless should note: (1) that a tumor consists of many different cell types (transformed neoplastic cells and various non-transformed cells, such as fibroblasts, endothelial cells, smooth muscle cells, and inflammatory cells), and (2) that, even within a single tumor, neoplastic cells are heterogeneous. ${ }^{37}$ While we should be aware of these caveats, neoplastic diseases still give opportunities to study epigenetic alterations in diseased cells, by providing relatively enriched disease cell population.

\section{Basic Characteristics of Disease: The Unique Disease Principle}

Human diseases are typically very complex processes (Figure 1), involving alterations in epigenomes, transcriptomes, proteomes, metabolomes, microbiomes, and interactomes. Because each of us has a unique genome, and distinct combinations of exposome ${ }^{38}$ epigenomes, transcriptomes, proteomes, and metabolomes in specific cell types, as well as unique microbiomes and interactomes in the tissue microenvironment, each disease process in each human must surely be unique, and distinct from what is nominally the same disease process in other 


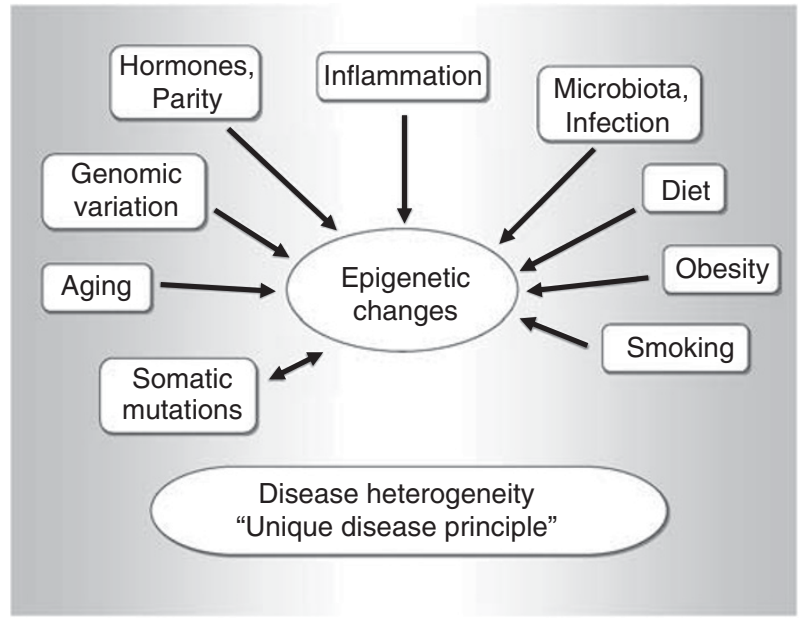

Figure 1 A variety of endogenous and exogenous etiological factors contribute to epigenetic changes leading to heterogeneity of disease processes, which is implicated by the 'unique disease principle'. To simplify, only selected examples of those etiological factors are demonstrated. There are numerous interactions between the factors, which are not depicted for simplicity.

individuals. This concept embodies the 'unique disease principle'.

To measure the contribution of each of the numerous molecular changes to disease pathogenesis will require enormous amounts of functional and correlative studies by both systems pathobiology and MPE approaches. Increasing roles of pathologists cannot be overemphasized in such efforts.

The 'unique disease principle' poses a challenge to epidemiological research, which is founded on the premise that we can predict disease occurrence and evolution, by inference from individuals with the disease with the same name. MPE, taking into account the unique disease principle, asserts that we can predict, to some extent, occurrence and evolution of a specific disease subtype by proper inference, which we will discuss further.

\section{MPE: Integrative Science}

MPE has evolved through the integration of molecular pathology and epidemiology. ${ }^{21-23}$ The MPE paradigm has widely been utilized in a number of original and review articles, ${ }^{39-62}$ while further conceptual development of MPE remains active. ${ }^{63-67}$

MPE differs from conventional molecular epidemiology. MPE addresses the fundamental heterogeneity of disease processes, while conventional molecular epidemiology generally treats a given disease as a single entity. ${ }^{65,66}$ The conceptual framework of MPE resembles that of systems biology, ${ }^{68,69}$ and MPE integrates analyses of populations and the macroenvironment, with those of molecules and microenvironment. Importantly, the MPE paradigm encompasses all human diseases.
The MPE research approach allows investigators to examine the relationships between potential etiological factors and disease subtypes based on molecular signatures. In addition, MPE permits the assessment of interactive effects of environmental influences and disease molecular signatures on disease progression..$^{70-74}$ Thus, MPE research can provide insights into disease pathogenesis by demonstrating how specific etiological factors influence mechanistic pathways in disease evolution and progression.

MPE possesses key advantages over traditional epidemiological or pathological research. Firstly, relationships can be uncovered between specific etiological factors and molecular subtypes, supporting causality, ${ }^{21,22}$ and etiological heterogeneity. ${ }^{67,75}$ Secondly, the risk of developing a specific disease subtype can be more accurately estimated. ${ }^{21,22}$ Thirdly, for individuals with susceptibility to a specific disease subtype or for patients with a specific disease subtype, personalized treatment and lifestyle modification strategies may be developed;21,22 examples include aspirin use for PIK3CA-mutant colorectal cancer patients, ${ }^{73}$ and physical activity recommendations for CTNNB1-negative colorectal cancer patients. ${ }^{72}$ These advantages are possible only with integrated MPE approach.

In the following sections, we describe how epigenetics has contributed to MPE, with an emphasis on major disease epigenotypes.

\section{Disease Epigenotypes}

While the unique disease principle emphasizes the individuality of each disease process, molecular disease classification attempts to identify commonality in disease features, subgroup disease based on these shared characteristics, and predict disease evolution, progression, and therapeutic response. ${ }^{64,76}$ Epigenotyping can successfully classify cancers in various organs into distinct groups with different clinical, pathological, and molecular characteristics. Currently, clinical utility of epigenotyping remains limited compared with conventional pathological assessment. However, accumulating evidence indicates distinct molecular signatures and phenotypes associated with specific epigenotypes, which cannot be discerned by pathological examination alone. Therefore, epigenotyping and pathological assessments should complement each other in the future.

\section{The CpG Island Methylator Phenotype}

A specific tumor phenotype appears to exist that is characterized by the propensity of tumor cells to acquire widespread $\mathrm{CpG}$ island hypermethylation. This phenotype was named the CpG island methylator phenotype (CIMP), and was first described in 
colorectal cancer. ${ }^{77}$ The CIMP concept is important because it draws attention to the presence of an epigenome-wide driving force for $\mathrm{CpG}$ island hypermethylation. Therefore, when assessing CpG island methylation at a particular locus, CIMP must always be considered as a potential confounder (Figure 2).

Normal differentiation state (including tissue of origin) likely influence epigenomic aberrations during neoplastic evolution. ${ }^{78}$ Although CIMP has been described in a variety of tumors, ${ }^{79-96}$ our discussion here focuses on colorectal cancer where CIMP has been most extensively characterized..$^{39,44,76,97-99}$ The pathogenic basis of CIMP remains elusive, and CIMP may represent a multifactorial phenomenon. ${ }^{22}$ Although CIMP-high (high-level CIMP) is strongly associated with $B R A F$ mutation in colorectal cancer, ${ }^{100-104}$ whether $B R A F$ mutation causes CIMP remains uncertain. ${ }^{105,106}$ DNA methyltransferase 3B (DNMT3B) overexpression has been implicated in CIMP-high (high-level CIMP). ${ }^{107-112}$ CIMP-high colorectal cancer has been thought to arise from serrated precursor lesions such as sessile serrated polyp/ adenoma. ${ }^{52,113-117}$ In addition to CIMP-high, a third CIMP category ('CIMP-low') in colorectal cancers was found to be associated with KRAS mutations, ${ }^{118}$ which was confirmed by multiple studies. ${ }^{119-129}$ Features of CIMP-low colorectal cancers have been characterized. ${ }^{118-134}$ Prognostic and predictive roles of CIMP remains uncertain. ${ }^{39,44,76,132,135-139}$

CIMP-high is the cause of most colorectal cancers displaying high levels of microsatellite instability (MSI-high), which occur as a result of epigenetic inactivation of the mismatch repair gene MLH1. ${ }^{100-102,140}$ CIMP-high in colorectal cancer is

a

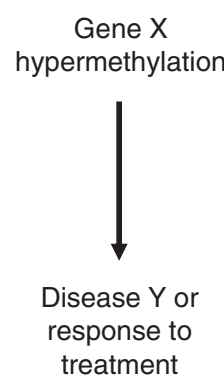
treatment

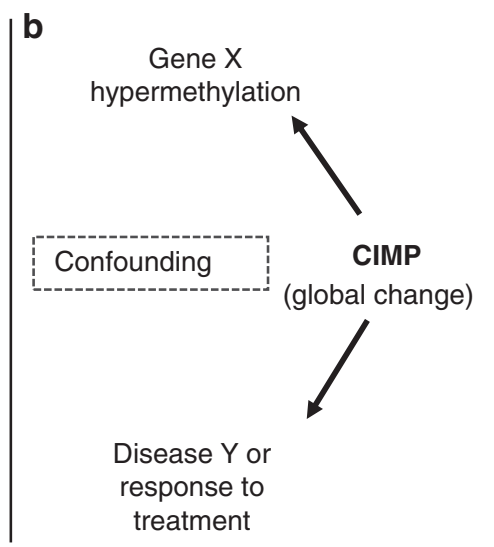

Figure 2 Why is examining global molecular phenomena so important? (a) A typical study examining the relationship between gene X hypermethylation and disease $\mathrm{Y}$, or response to treatment. Global molecular features, such as $\mathrm{CpG}$ island methylator phenotype (CIMP) status, are not often considered. (b) In reality, the significant relationship, if any, between gene $\mathrm{X}$ hypermethylation and disease, or treatment response, may reflect the association between CIMP and disease Y, or treatment response. CIMP status always needs to be considered as a potential confounder when examining locus-specific gene promoter hypermethylation and clinical outcome. associated with older age, female sex, proximal colonic location, ${ }^{100,103,141,142}$ poor tumor differentiation, mucinous and signet ring cell histology, ${ }^{143-146}$ immune and lymphocytic reactions, ${ }^{144,147-149}$ wild-type TP53, ${ }^{100,150}$ PTGS2 (cyclooxygenase-2) negativity, ${ }^{150}$ CDKN1A (p21) expression, ${ }^{151}$ loss of CDKN1B (p27) expression, ${ }^{152}$ CTNNB1 ( $\beta$-catenin) membrane localization, ${ }^{153}$ wild-type $A P C,{ }^{154}$ SIRT1 expression, ${ }^{155}$ PTGER2 expression, ${ }^{156}$ high levels of LINE-1 methylation, ${ }^{103,157}$ loss of CDX2 expression, ${ }^{158,159}$ and low-level chromosomal instability. ${ }^{160-163}$ Tumor invasiveness and budding phenotype are inversely associated with MSI-high, rather than CIMPhigh. ${ }^{164,165}$ Because BRAF mutation and MSI-high in colorectal cancer are associated with worse and better prognosis, respectively, ${ }^{121-123,132,166-182}$ it requires a large sample size and appropriate analyses to decipher prognostic significance of CIMP. ${ }^{132}$ CIMP-high is common in synchronous colorectal cancers (ie, multiple separate primary cancers in a single patient), ${ }^{183-185}$ indicating that colorectal epithelial cells may be predisposed to CpG island methylation due to genetic and/or environmental factors. ${ }^{183,186}$

Despite the importance of CIMP phenomena, several caveats exist in CIMP research. $44,76,187-190$ Firstly, there has been a relative lack of consensus and validation in CIMP analysis methodologies. ${ }^{44,188}$ Validation of each component of analytical procedures is essential, ${ }^{191-194}$ as is replication of study findings in independent studies. ${ }^{102,103,195}$ Secondly, most previous studies on CIMP in human cancer specimens had convenience cohorts ${ }^{196}$ with small sample sizes, causing spurious findings, lack of robust statistics, and lack of generalizability. ${ }^{22,23,196,197}$

\section{LINE-1 Methylation Epigenotypes}

Owing to the relative simplicity of the assay, methylation levels in the long interspersed nucleotide element-1 (LINE-1; also called long interspersed nuclear element-1; long interspersed element-1; L1) have commonly been used as a surrogate measurement of cellular global DNA methylation level. ${ }^{198-200}$ In addition to its role as a surrogate marker of global DNA hypomethylation, LINE-1 hypomethylation by itself may have functional implications. ${ }^{201,202}$ Activation of LINE-1 retrotransposons may lead to the transcription of adjacent genes, gene disruptions, chromosomal instability, or the generation of transcripts that regulate gene expression. ${ }^{203-208}$

LINE-1 methylation level in colorectal cancer is widely distributed. ${ }^{157,209,210}$ LINE-1 hypomethylation has been associated with poor outcome in several cancer types, ${ }^{211-215}$ including colon cancer. ${ }^{216-218}$ LINE-1 hypomethylation is common in esophageal squamous cell carcinoma, ${ }^{45}$ 
metastatic prostate cancer, ${ }^{219}$ and metastatic pancreatic endocrine tumors. ${ }^{220}$ Average LINE-1 methylation levels in colorectal tumors decline as tumors progress from adenomas to invasive cancers, to highly invasive cancers. ${ }^{111,221}$ LINE-1 hypomethylation in colorectal cancer is associated with chromosomal instability, ${ }^{210,222}$ IGF2BP3 overexpression, ${ }^{223}$ and hypomethylation at the IGF2 differentially methylated region-0, ${ }^{224}$ which may be a somatic event in carcinogenesis. ${ }^{225}$ LINE-1 hypomethylated colorectal cancers are associated with family history of colorectal cancer and younger age of onset. ${ }^{210,226-228}$ Given that synchronous colorectal cancers show concordant LINE-1 hypomethylation patterns, ${ }^{183}$ there may be a predisposition to LINE-1 hypomethylation in colorectal epithelial cells.

\section{Interplay of Genetic and Epigenetic Changes}

When we consider epigenetic alterations, which may have importance in any stage of tumor development, ${ }^{229}$ we also need to consider genetic changes, ${ }^{230-234}$ which may be causes or consequences of epigenetic alterations. Genetic changes are increasingly studied on routine formalin-fixed, paraffin-embedded archival tissue using next-generation sequencing technologies, ${ }^{235}$ which is opening up opportunities for pathology research.

Epigenetic silencing of the DNA repair gene MGMT is implicated in somatic $\mathrm{G}>\mathrm{A}$ mutations in various genes, including KRAS, PIK $3 C A, A P C$, and TP53. ${ }^{120,236-242}$ Furthermore, CIMP-high in colorectal cancer is causally linked to MSI through epigenetic inactivation of mismatch repair gene $M L H 1,{ }^{100-102,140}$ and then, MSI increases the rate of genome-wide mutational events, ${ }^{104,243-246}$ and influences cell cycle regulators. ${ }^{150-152,247-249}$ There are causally uncertain relations between $B R A F$ mutations and CIMP-high, ${ }^{100-103}$ and between KRAS mutations and CIMP-low. ${ }^{118-128}$

\section{MPE of Etiologies and Epigenetics}

Traditional epidemiology research has uncovered lifestyle, dietary, and environmental exposures that are positively or negatively associated with disease risk. In terms of cancer risk, these include smoking, some nutrients, alcohol consumption, energy metabolism status (energetics), aspirin use, hormone therapy, and some infectious/inflammatory conditions. However, generally, how these exposures influence disease pathogenesis remains not well understood. Lifestyle, dietary, and environmental factors likely influence the pathogenic process via altering the local tissue microenvironment, and epigenetics have a key role in cellular response to microenvironmental change.

Various studies have adopted an MPE design to address the roles of potential etiological factors. With the advent of technologies that enable analysis of genome-wide DNA methylation targets in archival tissue, ${ }^{250-252}$ we expect enormous opportunities to investigate environmental influences on somatic epigenetic alternations. Although this work is currently in its infancy, we highlight some examples, and the potential insights yielded, in the following sections.

\section{MPE of Cigarette Smoking and Epigenetics}

Cigarette smoking has been associated with CIMPhigh, ${ }^{253-256}$ MSI-high, ${ }^{253-260}$ and BRAF-mutant subtypes ${ }^{253-256,261}$ of colorectal cancer. Duration of smoking cessation is associated with a reduction of risk for CIMP-high colorectal cancer. ${ }^{256}$ Similar to colorectal cancer, smoking has been associated with hypermethylation of specific genes ${ }^{262,263}$ and $\mathrm{CIMP}^{81}$ in lung cancer.

\section{MPE of One-Carbon Metabolism and Epigenetics}

The methyl $\left(\mathrm{CH}_{3}-\right)$ groups for DNA methylation are derived from one-carbon methyl donors, suggesting an intrinsic link between one-carbon nutrients and epigenetic alterations. However, the relationship between one-carbon nutrients and somatic molecular alterations appears complex. ${ }^{16}$ In most epidemiological studies, low folate intake has been associated with an increased risk of colorectal cancer and adenomas. ${ }^{264}$ However, there have been concerns that supplementation with folic acid may have tumor-promoting effects. ${ }^{264-266}$ In mouse models, folate supplementation may promote epigenomic and microbiomic changes, and intestinal tumor formation. ${ }^{267,268}$ Examining molecular changes in tumor cells in relation to folate intake may provide insights into the role of one-carbon metabolism in carcinogenesis. ${ }^{22}$

Altered levels of intracellular folate metabolites have been linked to aberrant DNA methylation patterns. ${ }^{269,270}$ The relationship between folate/ alcohol intake and aberrant promoter hypermethylation in colorectal cancer remains unclear. ${ }^{124,271-277}$ The MTHFR rs1801131 polymorphism (codon 429) may (or may not ${ }^{124,278}$ ) be associated with CIMP-high cancer. ${ }^{279,280}$

With regard to LINE-1, or global DNA methylation level, experimental evidence suggests a link between folate deficiency and global DNA hypomethylation in the colonic epithelium. ${ }^{281}$ Folate supplementation increases global DNA methylation levels in glioma and colon cancer cells. ${ }^{282,283}$ Folate deficiency (or excess alcohol consumption) has been associated 
with increased risk of TP53-mutated, ${ }^{284}$ and LINE-1hypomethylated colon cancers. ${ }^{285}$ Randomized trials suggest that folic acid supplementation may (or may not $^{286}$ ) increase global DNA methylation levels in normal colonic mucosa. ${ }^{287}$ Collectively, there is suggestive evidence of a link between one-carbon nutrients and global DNA (LINE-1) hypomethylation, which may lead to carcinogenesis.

\section{MPE of Energetics and Epigenetics}

Energetics has been implicated in metabolic diseases and cancers. ${ }^{288-293}$ Nonetheless, analyses of potential links between energetics and epigenetic alterations in specific diseased cells are in their infancy.

Evidence suggests that caloric restriction in early life is associated with a lower risk of CIMPhigh colorectal cancer. ${ }^{294}$ In contrast, obesity in adult has been associated with non-MSI colorectal cancer, ${ }^{49,295-297}$ and CIMP-low/negative colorectal cancer. ${ }^{274}$ A recent prospective study has shown that obesity is associated with an increased risk of fatty acid synthase (FASN)-negative colorectal cancer. ${ }^{298}$ FASN overexpression has been implicated in carcinogenesis, ${ }^{299,300}$ and associated with MSIhigh colorectal cancer. ${ }^{301}$ The relationship between obesity and non-MSI (or CIMP-low/negative) cancer might be explained by the link between obesity and FASN-negative tumors. ${ }^{21}$

Energetic status has been shown to interact with tumor molecular signatures to modify the behavior of colorectal cancer. Such tumor markers include expression of CTNNB1 ( $\beta$-catenin), ${ }^{72}$ FASN, ${ }^{70}$ PRKAA (AMP-activated protein kinase), ${ }^{302}$ STMN1, ${ }^{303}$ CDKN1A (p21), ${ }^{304}$ and CDKN1B (p27). ${ }^{305,306}$ This type of interaction analysis represents an emerging paradigm in MPE, ${ }^{21,22}$ and may inform the design of new clinical trials to assess lifestyle or pharmacological interventions.

\section{Endogenous and Exogenous Hormones, and Epigenetics}

Hormone therapy has been linked to lower risk of certain cancers, but epigenetic and other molecular mechanisms remain poorly understood. In breast cancer, ESR1 (estrogen receptor 1) and PGR (progesterone receptor) expression status has been associated with methylome alteration patterns. ${ }^{307}$ Hormone therapy has been associated with ESR1 and $P G R$ promoter methylation in colorectal cancer. ${ }^{308}$ However, recent prospective cohort studies failed to demonstrate a clear relationship between hormone therapy and CIMP status. ${ }^{47,48,309}$ Hormone therapy may be associated with a decreased risk of colorectal cancer lacking CDKN1A (p21) expression. ${ }^{309}$ There are possible interrelations between the vitamin $\mathrm{D}$ pathway, the RAS-PI3K-AKT pathway, and epigenetic modulations in colorectal cancer. ${ }^{310,311}$

\section{Microbiota, Inflammation, Immunity, and Epigenetics}

Microorganisms, such as viruses, bacteria, and parasites, have been increasingly implicated in human health and chronic disease. ${ }^{19,20,312}$ Recently, the interplay of microenvironment, microbiota, immunity, inflammation, cellular epigenetic alterations, and various chronic diseases has attracted increasing attention. ${ }^{15,17-20,23,59,313-316}$ Helicobacter pylori infection has been associated with epigenetic changes in gastric epithelial cells, 317,318 and Enterobacteriaceae and Tenericutes have been associated with epigenetic changes in head and neck squamous cell carcinoma. ${ }^{319}$

The role of viral infection in epigenetic changes has been extensively reviewed elsewhere. ${ }^{320}$ Evidence indicate roles of HBV, HPV, and EBV in epigenetic alterations and carcinogenesis. ${ }^{320-323}$ In colorectal cancer, a role of JCV in epigenetic alterations has been controversial. ${ }^{324-326}$

Inflammation appears to have a crucial role in carcinogenesis, ${ }^{327-329}$ and has been linked to energetics, ${ }^{330,331}$ and epigenetics. ${ }^{332}$ Cellular epigenetic changes may be induced by inflammation and associated oxidative damage, ${ }^{333-335}$ while cellular epigenetic aberrations may cause inflammatory diseases. ${ }^{336}$ A study has demonstrated that the inflammatory mediator, prostaglandin E2, upregulates DNMT3B, resulting in promoter CpG island hypermethylation and promotion of intestinal tumorigenesis in mice. ${ }^{335}$ Regular use of antiinflammatory drugs such as aspirin, an inhibitor of PTGS2 (cyclooxygenase 2), has been associated with a decrease in cancer incidence and mortality, ${ }^{57,329}$ Cancer-preventive effect of aspirin is apparent against PTGS2-positive colorectal cancer. ${ }^{71,337,338}$ Moreover, aspirin appears to be very effective to treat PIK3CA-mutated colorectal cancer, suggesting PIK3CA mutation as a predictive tumor biomarker for clinical use. ${ }^{73}$

The importance of tumor-host interactions, encompassing microbiota and inflammation, has been highlighted by the recent discovery of a continuum in the frequency of molecular features (including CIMP-high, MSI-high, and BRAF mutation) in colorectal cancers along subsites in the proximal-distal axis of the bowel. ${ }^{142,339}$ Luminal microbial contents and immune infiltrates appear to change gradually along the bowel. ${ }^{142,339-341}$ Taken together, local host and environmental factors, such as luminal contents, microbiome, inflammation, and the innate immune response, likely contribute to the development of specific molecular subtypes of colorectal cancer. ${ }^{142}$ 


\section{Implications of MPE in Disease Prevention and Therapy}

Despite the 'uniqueness' of each disease process, molecular disease classification exploits shared molecular features of disease processes in multiple patients, on the premise that disease evolution and progression can be, to some extent, generalized to other patients with the same molecular subtype, and that appropriate ('personalized' or 'precise') treatment measures can be initiated for the patients with the particular disease subtype. ${ }^{64,76}$ Essentially, pathology testing can guide treatment decision-making. This is relevant to not only pharmacological and immunological interventions ${ }^{23,73}$ but also to lifestyle modifications. ${ }^{72,306}$

With regard to disease prevention, MPE research may identify risk factors for a specific disease subtype. For individuals who are susceptible to the specific disease subtype, appropriate preventive measures (such as avoiding the identified risk factors) can be taken, or early detection can be attempted. For example, genetic susceptibility and familial clustering have been suggested for colorectal cancer with LINE-1 hypomethylation, ${ }^{210,226-228}$ which is an aggressive subtype ${ }^{216-218}$ but can be prevented by adequate folate intake and avoidance of alcohol. ${ }^{285}$

\section{Analysis of Normal Tissue, Stool, Blood, or Other Body Fluids in MPE Context}

To date, most epigenetic studies on non-neoplastic diseases have relied on blood leukocytes as a surrogate for molecular processes in diseased cells, ${ }^{24-27,29,30,33,34}$ although there is very little evidence supporting the validity of this approach in non-hematological diseases. Thus, the following discussion focuses on epigenetic or other molecular analyses of normal tissues or blood in the context of the MPE of cancer epigenetics. The ability to detect cancer or estimate cancer risk from normal tissue, stool, peripheral blood, or other body fluids (such as sputum and urine) has become the holy grail of biomarker discovery. ${ }^{342}$ Biomarkers in normal tissue, stool, or body fluids can represent: (1) a pathological outcome, analogous to established serum tumor markers; (2) a surrogate or shared indicator of etiological exposure and disease predisposition; or (3) an intermediary in a causal pathway from etiology to downstream outcome (cancer incidence or behavior). Analysis of normal tissue, stool, and body fluids can expand the scope of, and add a novel dimension to, MPE research (Figure 3).

Bearing in mind the limitations of epigenetic and other molecular analyses on plasma or peripheral blood leukocytes, blood can conceivably carry a pathological molecular signature, or diseased cells or cellular constituents, from any part of the body

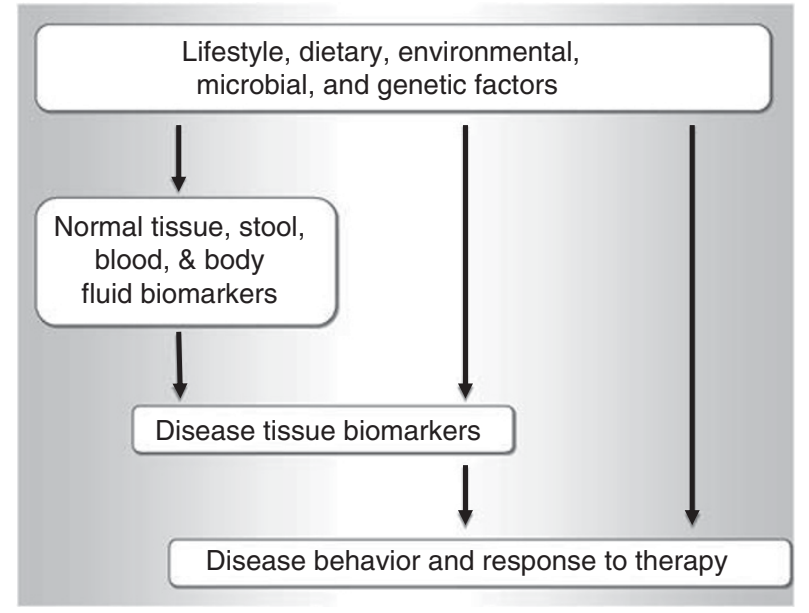

Figure 3 Biomarker analysis in normal tissue, stool, blood, and body fluids adds new dimensions to molecular pathological epidemiology (MPE) research. Analyses of interactions among etiological factors and biomarkers can be performed to test a specific research hypothesis. $^{22,23,72,73}$

(eg, bone marrow ${ }^{343}$ ). As a result of its abundance, ease of specimen collection, and practicality as a future clinical test, blood has been a common specimen type for studies on epigenetic changes in 'normal' cells. Global DNA or LINE-1 methylation in leukocytes has attracted much interest as a potential cancer biomarker. ${ }^{344}$ Alterations in leukocyte DNA methylation have been associated with risk for a variety of solid tumors, including colon, bladder, stomach, and breast cancers. ${ }^{344-347}$ LINE-1 methylation level and other epigenetic changes in leukocytes appear to be influenced by a variety of exposures, including smoking, early life, or prenatal events. ${ }^{27,345-348}$ LINE-1 methylation in leukocytes and normal tissues is less variable compared with tumor, and may not correlate with tumor LINE-1 methylation levels. ${ }^{194,209,210,263,349}$

The study of interrelations between epidemiological exposures, molecular changes in normal tissue or biological specimens, and cancer and other chronic diseases is an evolving field. ${ }^{350,351}$ Notably, several caveats must be applied to inferences drawn from study findings to date. Most studies have been relatively small and crosssectional or retrospective in design, and replication in larger prospective studies is required. The type of assay employed and specific cell type analyzed appear to influence critically the determination of cellular DNA methylation levels. ${ }^{346-349,351-354}$ There is a relative lack of uniformity and robust validation data across laboratories in cell or nucleic-acid isolation protocols, downstream processing, and assays. It remains a challenge to define exact biological mechanisms to account for the associations between epigenetic alterations in normal blood and pathobiological changes in specific cell types (eg, breast duct epithelial cells that give rise to 
neoplasia). This has limited the potential for insights into disease pathogenesis and causality. Although blood biomarkers have the capability to reflect a disease process at a distant site in the body, epigenetic biomarkers, such as global DNA methylation in leukocytes, are often rather nonspecific, and may be associated with a variety of different cancer types, as well as non-malignant conditions. ${ }^{27,345-347}$

\section{Role of MPE in Post-GWAS Era}

Over the past decade, GWAS have identified many germline genetic variants associated with numerous multifactorial diseases, ${ }^{355}$ and next steps such as fine locus mapping, gene-environment interaction analysis, family history analysis, and population structure analysis have been initiated. ${ }^{38,355-361}$ However, GWAS findings have made virtually no impact on clinical medicine and public health. Major shortcomings of existing GWAS approaches include insufficient consideration of disease heterogeneity, ${ }^{22}$ and relative lack of follow-up functional analyses of risk variants. ${ }^{362,363}$

Recently, the 'GWAS-MPE approach' was proposed, ${ }^{22}$ to take disease heterogeneity into account following GWAS analyses. In a typical GWAS design, a disease of interest is regarded as a single entity without consideration of etiological and biological heterogeneity. Epigenetic analysis of diseased cells can provide ample opportunities to study biological significance of GWAS findings. By employing the MPE approach, molecular disease classification can help to identify a specific disease subtype that is more strongly associated with a given risk variant than other subtypes of the same disease. The 'GWAS-MPE approach' has been applied to epidemiology research. ${ }^{364-366}$ The 'GWAS-MPE approach'22 has advantages: (1) it may provide a possible causal link between the risk variant and molecular signatures in diseased cells; (2) it can more precisely refine risk estimates for each molecular subtype; and (3) it may identify new variant-subtype relationships, which may otherwise be obscured in conventional GWAS, dealing only with overall disease risk.

\section{Problems in Epigenome-Wide Association Study}

After flourishing GWAS research over the past decade, epigenome-wide association studies are attracting increasing attention. ${ }^{367}$ However, we must be aware of significant flaws and caveats associated with current epigenome-wide association study design. ${ }^{368}$ In essence, each human being possesses innumerable different epigenomes. Epigenomes differ between cell types even within a single organ (which consists of numerous different cell types). Even in a single cell, the epigenome changes over time in dynamic timevarying macro- and microenvironmental milieu. Despite the presence of numerous epigenomes in each individual, current epigenome-wide association study design assumes one representative epigenome for each individual. Furthermore, it is unlikely a totally valid approach to infer epigenomic variants in specific cells (non-leukocytes) from epigenomic analysis of leukocytes.

At this juncture, we must be prudent, and first develop the required technologies and biosensors capable of interrogating epigenomic variations and interactomes in different cell types (preferably, in vivo) in one human being. This is prerequisite for launching into very expensive, resource-intensive epigenome-wide association study consortia, which presently erroneously assume a single epigenome to be representative of all epigenomes in an individual.

\section{Conclusions and Future Perspectives}

Achieving the goal of personalized medicine and prevention requires the integration of molecular medicine and population health sciences, and the willingness to explore beyond conventional disease classification. Personalized medicine holds the promise of biomarkers that will help stratify patients and guide decisions on optimal disease treatment and prevention. ${ }^{369}$ However, there is an increasing gap between basic scientific discoveries and real impact on population health. ${ }^{370,371}$ Recently, MPE has emerged as the evolving transdisciplinary science that can help fill in this gap. ${ }^{21,22,65,66}$ MPE integrates molecular pathology and epidemiology, in an attempt to decipher disease at the molecular, cellular, organ, individual, and population levels. The application of molecular pathology is feasible in existing cohort studies with large amounts of accumulated multidimensional data on dietary, lifestyle and environmental exposures, and clinical outcomes. This represents a very cost-efficient research approach to advance our understanding of disease and improve medicine and public health. ${ }^{49,63,372-375}$ To advance this integrated science requires cooperation of all practicing pathologists, because it is necessary to gather tissue specimens (from various community and academic pathology laboratories, to minimize selection bias) within well-defined cohort populations for molecular analyses.

Most chronic diseases are complex, multifactorial, genetic, and epigenetic diseases. Epigenetic research is promising because epigenetic mechanisms have critical roles in the regulation of cellular growth, differentiation, and behavior, and epigenetic changes are potential modifiable targets for therapy and chemoprevention. Analysis of normal tissue, and biological specimens, adds additional dimensions to MPE research, through we must keep in mind caveats of analysis of those specimens. 
Epigenetic analyses continue to contribute substantially to biomedical and population health sciences. The future widespread application of methylome and epigenome analyses ${ }^{250,376-378}$ to paraffinembedded archival tissues represents a powerful investigative tool, capable of enhancing our understanding of disease heterogeneity and hostdisease interactions. In the future, application of in vivo real-time molecular pathology, encompassing genomic, epigenomic, transcriptomic, proteomic, metabolomic, microbiomic, and interactomic analyses, will further transform biomedical and population health sciences.

Ultimately, molecular disease classification should be the primary pathophenotypic datum of entry in population registries and databases around the world; this will further advance integrated population health science. There has been and will be increasing contribution of modern pathology to broader public health sciences, which attests pivotal roles of pathologists in the integrated science towards our ultimate goal of personalized medicine and prevention.

\section{Note added in proof}

Spitz et $a l^{379}$ have used the term 'integrative epidemiology' to describe an integration of molecular analyses (on exposures and tumors) into epidemiology. Integrative epidemiology encompasses MPE and conventional molecular epidemiology. MPE differs from conventional epidemiology because MPE takes disease heterogeneity into analysis.

\section{Acknowledgements}

This work was supported by grants from USA National Institute of Health (NIH) (R01 CA151993 (to SO), R01 CA137178 (to ATC), R01 CA136950 (to EC), R01 CA149222 (to JAM), P50 CA127003 (to CSF), R01 CA124908 (to CSF), P01 CA87969 (to SE Hankinson), and 1UM1 CA167552 (to WC Willett)). PL is a Scottish Government Clinical Academic Fellow. ATC is a Damon Runyon Clinical Investigator. The content is solely the responsibility of the authors and does not necessarily represent the official views of NIH. Funding agencies did not have any role in the decision to submit the manuscript for publication, or the writing of the manuscript.

\section{Disclosure/conflict of interest}

ATC was a consultant of Bayer Healthcare, Millennium Pharmaceuticals, and Pfizer Inc. This work was not funded by Bayer Healthcare, Millennium Pharmaceuticals, or Pfizer Inc. The other authors declare no conflict of interest.

\section{References}

1 Baylin SB, Jones PA. A decade of exploring the cancer epigenome-biological and translational implications. Nat Rev Cancer 2011;11:726-734.

2 Jones PA. Functions of DNA methylation: islands, start sites, gene bodies and beyond. Nat Rev Genet 2012;13:484-492.

3 Park J, Xu K, Park T, et al. What are the determinants of gene expression levels and breadths in the human genome? Hum Mol Genet 2012;21:46-56.

4 Rodriguez-Paredes M, Esteller M. Cancer epigenetics reaches mainstream oncology. Nat Med 2011;17: 330-339.

5 Juergens RA, Wrangle J, Vendetti FP, et al. Combination epigenetic therapy has efficacy in patients with refractory advanced non-small cell lung cancer. Cancer Discov 2011;1:598-607.

6 Ebert MP, Tanzer M, Balluff B, et al. TFAP2E-DKK4 and chemoresistance in colorectal cancer. N Engl J Med 2012;366:44-53.

7 de Krijger I, Mekenkamp LJ, Punt CJ, et al. MicroRNAs in colorectal cancer metastasis. J Pathol 2011;224:438-447.

8 Wang F, Ma YL, Zhang P, et al. SP1 mediates the link between methylation of the tumour suppressor miR149 and outcome in colorectal cancer. J Pathol 2013;229:12-24.

9 Valeri N, Gasparini P, Fabbri M, et al. Modulation of mismatch repair and genomic stability by miR-155. Proc Natl Acad Sci USA 2010;107:6982-6987.

10 Valeri N, Gasparini P, Braconi C, et al. MicroRNA-21 induces resistance to 5-fluorouracil by down-regulating human DNA MutS homolog 2 (hMSH2). Proc Natl Acad Sci USA 2010;107:21098-21103.

11 Bartley AN, Yao H, Barkoh BA, et al. Complex patterns of altered microRNA expression during the adenoma-adenocarcinoma sequence for microsatellite-stable colorectal cancer. Clin Cancer Res 2011; 17:7283-7293.

12 Earle JS, Luthra R, Romans A, et al. Association of microRNA expression with microsatellite instability status in colorectal adenocarcinoma. J Mol Diagn 2010;12:433-440.

13 Alhopuro P, Sammalkorpi H, Niittymaki I, et al. Candidate driver genes in microsatellite-unstable colorectal cancer. Int J Cancer 2012;130:1558-1566.

14 Waldron L, Ogino S, Hoshida Y, et al. Expression profiling of archival tissues for long-term health studies. Clin Cancer Res 2012;18:6136-6146.

15 Stein RA. Epigenetics-the link between infectious diseases and cancer. JAMA 2011;305:1484-1485.

16 Coppede F. Epigenetic biomarkers of colorectal cancer: focus on DNA methylation. Cancer Lett 2012; in press (published online).

17 Kostic AD, Gevers D, Pedamallu CS, et al. Genomic analysis identifies association of Fusobacterium with colorectal carcinoma. Genome Res 2012;22:292-298.

18 Castellarin M, Warren RL, Freeman JD, et al. Fusobacterium nucleatum infection is prevalent in human colorectal carcinoma. Genome Res 2012;22:299-306.

19 Cho I, Blaser MJ. The human microbiome: at the interface of health and disease. Nat Rev Genet 2012;13:260-270.

20 Tjalsma H, Boleij A, Marchesi JR, et al. A bacterial driver-passenger model for colorectal cancer: beyond the usual suspects. Nat Rev Microbiol 2012;10:575-582. 
21 Ogino S, Stampfer M. Lifestyle factors and microsatellite instability in colorectal cancer: the evolving field of molecular pathological epidemiology. J Natl Cancer Inst 2010;102:365-367.

22 Ogino S, Chan AT, Fuchs CS, et al. Molecular pathological epidemiology of colorectal neoplasia: an emerging transdisciplinary and interdisciplinary field. Gut 2011;60:397-411.

23 Ogino S, Galon J, Fuchs CS, et al. Cancer immunology-analysis of host and tumor factors for personalized medicine. Nat Rev Clin Oncol 2011;8:711-719.

24 Baccarelli A, Wright R, Bollati V, et al. Ischemic heart disease and stroke in relation to blood DNA methylation. Epidemiology 2010;21:819-828.

25 Bind M, Baccarelli A, Zanobetti A, et al. Air pollution and markers of coagulation, inflammation, and endothelial function: associations and epigeneenvironment interactions in an elderly cohort. Epidemiology 2012;23:332-340.

26 Tang WY, Levin L, Talaska G, et al. Maternal exposure to polycyclic aromatic hydrocarbons and 5'-CpG methylation of interferon-gamma in cord white blood cells. Environ Health Perspect 2012;120:1195-1200.

27 Flom JD, Ferris JS, Liao Y, et al. Prenatal smoke exposure and genomic DNA methylation in a multiethnic birth cohort. Cancer Epidemiol Biomarkers Prev 2011;20:2518-2523.

28 Hernandez DG, Nalls MA, Gibbs JR, et al. Distinct DNA methylation changes highly correlated with chronological age in the human brain. Hum Mol Genet 2011;20:1164-1172.

29 Wan ES, Qiu W, Baccarelli A, et al. Cigarette smoking behaviors and time since quitting are associated with differential DNA methylation across the human genome. Hum Mol Genet 2012;21:3073-3082.

30 Dempster EL, Pidsley R, Schalkwyk LC, et al. Disease-associated epigenetic changes in monozygotic twins discordant for schizophrenia and bipolar disorder. Hum Mol Genet 2011;20:4786-4796.

31 Ollikainen M, Smith KR, Joo EJ, et al. DNA methylation analysis of multiple tissues from newborn twins reveals both genetic and intrauterine components to variation in the human neonatal epigenome. Hum Mol Genet 2010;19:4176-4188.

32 Byun HM, Siegmund KD, Pan F, et al. Epigenetic profiling of somatic tissues from human autopsy specimens identifies tissue- and individual-specific DNA methylation patterns. Hum Mol Genet 2009;18:4808-4817.

33 Toperoff G, Aran D, Kark JD, et al. Genome-wide survey reveals predisposing diabetes type 2-related DNA methylation variations in human peripheral blood. Hum Mol Genet 2012;21:371-383.

34 Lambrou A, Baccarelli A, Wright RO, et al. Arsenic exposure and DNA methylation among elderly men. Epidemiology 2012;23:668-676.

35 Huang WY, Su LJ, Hayes RB, et al. Prospective study of genomic hypomethylation of leukocyte DNA and colorectal cancer risk. Cancer Epidemiol Biomarkers Prev 2012;21:2014-2021.

36 Gao Y, Killian K, Zhang $\mathrm{H}$, et al. Leukocyte DNA methylation and colorectal cancer among male smokers. World J Gastrointest Oncol 2012;4:193-201.

37 Marusyk A, Almendro V, Polyak K. Intra-tumor heterogeneity: a looking glass for cancer. Nat Rev Cancer 2012;12:323-334.
38 Thomas DC, Lewinger JP, Murcray CE, et al. Invited commentary: GE-Whiz! Ratcheting geneenvironment studies up to the whole genome and the whole exposome. Am J Epidemiol 2012;175: 203-207; discussion 208-209.

39 Curtin K, Slattery ML, Samowitz WS. CpG island methylation in colorectal cancer: past, present and future. Pathology Res Int 2011;2011:902674.

40 Hughes LA, Simons CC, van den Brandt PA, et al. Body size, physical activity and risk of colorectal cancer with or without the $\mathrm{CpG}$ island methylator phenotype (CIMP). PLoS One 2011;6:e18571.

41 Kelley RK, Wang G, Venook AP. Biomarker use in colorectal cancer therapy. J Natl Compr Canc Netw 2011;9:1293-1302.

42 Campbell PT, Newton CC, Dehal AN, et al. Impact of body mass index on survival after colorectal cancer diagnosis: The Cancer Prevention Study-II Nutrition Cohort. J Clin Oncol 2012;30:42-52.

43 Gehoff A, Basten O, Sprenger T, et al. Optimal lymph node harvest in rectal cancer (UICC Stages II and III) after preoperative 5-FU-based radiochemotherapy. acetone compression is a new and highly efficient method. Am J Surg Pathol 2012;36:202-213.

44 Hughes LA, Khalid-de Bakker CA, Smits KM, et al. The CpG island methylator phenotype in colorectal cancer: Progress and problems. Biochim Biophys Acta 2012;1825:77-85.

45 Iwagami S, Baba Y, Watanabe $\mathrm{M}$, et al. Pyrosequencing assay to measure LINE-1 methylation level in esophageal squamous cell carcinoma. Ann Surg Oncol 2012;19:2726-2732.

46 Esteban S, Moya P, Fernandez-Suarez A, et al. Diagnostic and prognostic utility of methylation and protein expression patterns of myopodin in colon cancer. Tumour Biol 2012;33:337-346.

47 Limburg PJ, Limsui D, Vierkant RA, et al. Postmenopausal hormone therapy and colorectal cancer risk in relation to somatic KRAS mutation status among older women. Cancer Epidemiol Biomarkers Prev 2012;21:681-684.

48 Limsui D, Vierkant RA, Tillmans LS, et al. Postmenopausal hormone therapy and colorectal cancer risk by molecularly defined subtypes among older women. Gut 2012;61:1299-1305.

49 Hughes LA, Williamson EJ, van Engeland M, et al. Body size and risk for colorectal cancers showing BRAF mutation or microsatellite instability: a pooled analysis. Int J Epidemiol 2012;41:1060-1072.

$50 \mathrm{Ku}$ CS, Cooper DN, Wu M, et al. Gene discovery in familial cancer syndromes by exome sequencing: prospects for the elucidation of familial colorectal cancer type X. Mod Pathol 2012;25:1055-1068.

51 Kanthan R, Senger JL, Kanthan SC. Molecular events in primary and metastatic colorectal carcinoma: a review. Pathol Res Int 2012;2012:597497.

52 Rex DK, Ahnen DJ, Baron JA, et al. Serrated lesions of the colorectum: review and recommendations from an expert panel. Am J Gastroenterol 2012;107: 1315-1329.

53 Koshiol J, Lin SW. Can tissue-based immune markers be used for studying the natural history of cancer? Ann Epidemiol 2012;22:520-530.

54 Patai AV, Molnar B, Kalmar A, et al. Role of DNA methylation in colorectal carcinogenesis. Dig Dis 2012;30:310-315. 
55 Fini L, Grizzi F, Laghi L. Adaptive and innate immunity, non clonal players in colorectal cancer progression, In: Ettarh R (ed). Colorectal Cancer Biology—From Genes to Tumor. InTech, 2012, pp 323-340.

56 Gay LJ, Mitrou PN, Keen J, et al. Dietary, lifestyle and clinico-pathological factors associated with APC mutations and promoter methylation in colorectal cancers from the EPIC-Norfolk Study. J Pathol 2012;228:405-415.

57 Chia WK, Ali R, Toh HC. Aspirin as adjuvant therapy for colorectal cancer-reinterpreting paradigms. Nat Rev Clin Oncol 2012;9:561-570.

58 Dogan S, Shen R, Ang DC, et al. Molecular epidemiology of EGFR and KRAS mutations in 3026 lung adenocarcinomas: higher susceptibility of women to smoking-related KRAS-mutant cancers. Clin Cancer Res 2012;18:6169-6177.

59 Galon J, Franck P, Marincola FM, et al. Cancer classification using the Immunoscore: a worldwide task force. J Transl Med 2012;10:205.

60 Haq S, Ali S, Mohammad R, et al. The complexities of epidemiology and prevention of gastrointestinal cancers. Int J Mol Sci 2012;13:12556-12572.

61 Boyle T, Fritschi L, Heyworth J, et al. Long-term sedentary work and the risk of subsite-specific colorectal cancer. Am J Epidemiol 2011;173: 1183-1191.

62 Jacobs R, Voorneveld P, Kodach L, et al. Cholesterol metabolism and colorectal cancers. Curr Opin Pharmacol 2012;12:690-695.

63 Ogino S, Giovannucci E. Commentary: lifestyle factors and colorectal cancer microsatellite instability-molecular pathological epidemiology science, based on unique tumour principle. Int J Epidemiol 2012;41:1072-1074.

64 Ogino S, Fuchs CS, Giovannucci E. How many molecular subtypes? Implications of the unique tumor principle in personalized medicine. Expert Rev Mol Diagn 2012;12:621-628.

65 Ogino S, King EE, Beck AH, et al. Interdisciplinary education to integrate pathology and epidemiology: towards molecular and population-level health science. Am J Epidemiol 2012;176:659-667.

66 Ogino S, Beck AH, King EE, et al. Ogino et al. respond to 'The 21st century epidemiologist'. Am J Epidemiol 2012;176:672-674.

67 Begg CB, Zabor EC. Detecting and exploiting etiologic heterogeneity in epidemiologic studies. Am J Epidemiol 2012;176:512-518.

68 Ghosh S, Matsuoka Y, Asai Y, et al. Software for systems biology: from tools to integrated platforms. Nat Rev Genet 2011;12:821-832.

69 Papp B, Notebaart RA, Pal C. Systems-biology approaches for predicting genomic evolution. Nat Rev Genet 2011;12:591-602.

70 Ogino S, Nosho K, Meyerhardt JA, et al. Cohort study of fatty acid synthase expression and patient survival in colon cancer. J Clin Oncol 2008;26:5713-5720.

71 Chan AT, Ogino S, Fuchs CS. Aspirin use and survival after diagnosis of colorectal cancer. JAMA 2009;302:649-658.

72 Morikawa T, Kuchiba A, Yamauchi M, et al. Association of CTNNB1 (beta-catenin) alterations, body mass index, and physical activity with survival in patients with colorectal cancer. JAMA 2011; 305:1685-1694
73 Liao X, Lochhead P, Nishihara R, et al. Aspirin use, tumor PIK3CA mutation status, and colorectal cancer survival. N Engl J Med 2012;367:1596-1606.

74 Pasche B. Aspirin-from prevention to targeted therapy. N Engl J Med 2012;367:1650-1651.

75 Begg CB. A strategy for distinguishing optimal cancer subtypes. Int J Cancer 2011;129:931-937.

76 Ogino S, Goel A. Molecular classification and correlates in colorectal cancer. J Mol Diagn 2008;10: 13-27.

77 Toyota M, Ahuja N, Ohe-Toyota M, et al. CpG island methylator phenotype in colorectal cancer. Proc Natl Acad Sci USA 1999;96:8681-8686.

78 Sproul D, Kitchen RR, Nestor CE, et al. Tissue of origin determines cancer-associated CpG island promoter hypermethylation patterns. Genome Biol 2012;13:R84

79 Noushmehr H, Weisenberger DJ, Diefes $\mathrm{K}$, et al. Identification of a $\mathrm{CpG}$ island methylator phenotype that defines a distinct subgroup of glioma. Cancer Cell 2010;17:510-522.

80 Turcan S, Rohle D, Goenka A, et al. IDH1 mutation is sufficient to establish the glioma hypermethylator phenotype. Nature 2012;483:479-483.

81 Shinjo K, Okamoto Y, An B, et al. Integrated analysis of genetic and epigenetic alterations reveals $\mathrm{CpG}$ island methylator phenotype associated with distinct clinical characters of lung adenocarcinoma. Carcinogenesis 2012;33:1277-1285.

82 The Cancer Genome Atlas Research Network. Integrated genomic analyses of ovarian carcinoma. Nature 2011;474:609-615.

83 Kolbe DL, Deloia JA, Porter-Gill P, et al. Differential analysis of ovarian and endometrial cancers identifies a methylator phenotype. PLoS One 2012; 7:e32941.

84 Ueki T, Toyota M, Sohn T, et al. Hypermethylation of multiple genes in pancreatic adenocarcinoma. Cancer Res 2000;60:1835-1839.

85 Suzuki M, Shigematsu H, Iizasa T, et al. Exclusive mutation in epidermal growth factor receptor gene, HER-2, and KRAS, and synchronous methylation of nonsmall cell lung cancer. Cancer 2006;106: 2200-2207.

86 Shaw RJ, Hall GL, Lowe D, et al. CpG island methylation phenotype (CIMP) in oral cancer: associated with a marked inflammatory response and less aggressive tumour biology. Oral Oncol 2007;43: 878-886.

87 Tanemura A, Terando AM, Sim MS, et al. CpG island methylator phenotype predicts progression of malignant melanoma. Clin Cancer Res 2009;15:1801-1807.

88 Toyota M, Ahuja N, Suzuki H, et al. Aberrant methylation in gastric cancer associated with the CpG island methylator phenotype. Cancer Res 1999; 59:5438-5442.

89 Fang F, Turcan S, Rimner A, et al. Breast cancer methylomes establish an epigenomic foundation for metastasis. Sci Transl Med 2011;3:75ra25.

90 Warth A, Kloor M, Schirmacher P, et al. Genetics and epigenetics of small bowel adenocarcinoma: the interactions of CIN, MSI, and CIMP. Mod Pathol 2011;24:564-570.

91 Abe M, Watanabe N, McDonell N, et al. Identification of genes targeted by CpG island methylator phenotype in neuroblastomas, and their possible integra- 
tive involvement in poor prognosis. Oncology 2008; 74:50-60.

92 Yagi K, Takahashi H, Akagi K, et al. Intermediate methylation epigenotype and its correlation to KRAS mutation in conventional colorectal adenoma. Am J Pathol 2012;180:616-625.

93 Duncan CG, Barwick BG, Jin G, et al. A heterozygous IDH1R132H/WT mutation induces genome-wide alterations in DNA methylation. Genome Res 2012; 22:2339-2355.

94 Park SY, Kwon HJ, Choi Y, et al. Distinct patterns of promoter $\mathrm{CpG}$ island methylation of breast cancer subtypes are associated with stem cell phenotypes. Mod Pathol 2012;25:185-196.

95 Zouridis H, Deng N, Ivanova T, et al. Methylation subtypes and large-scale epigenetic alterations in gastric cancer. Sci Transl Med 2012;4:156ra140.

96 Yamamoto E, Suzuki H, Yamano HO, et al. Molecular dissection of premalignant colorectal lesions reveals early onset of the CpG island methylator phenotype. Am J Pathol 2012;181:1847-1861.

97 Lao VV, Grady WM. Epigenetics and colorectal cancer. Nat Rev Gastroenterol Hepatol 2011;8: $686-700$.

98 Greystoke A, Mullamitha SA. How many diseases is colorectal cancer? Gastroenterol Res Pract 2012;2012:564741.

99 Beggs AD, Jones A, El-Bahwary $\mathrm{M}$, et al. Wholegenome methylation analysis of benign and malignant colorectal tumours. J Pathol 2013 (in press).

100 Samowitz W, Albertsen H, Herrick J, et al. Evaluation of a large, population-based sample supports a CpG island methylator phenotype in colon cancer. Gastroenterology 2005;129:837-845.

101 Ogino S, Cantor M, Kawasaki T, et al. CpG island methylator phenotype (CIMP) of colorectal cancer is best characterised by quantitative DNA methylation analysis and prospective cohort studies. Gut 2006;55:1000-1006.

102 Weisenberger DJ, Siegmund KD, Campan M, et al. $\mathrm{CpG}$ island methylator phenotype underlies sporadic microsatellite instability and is tightly associated with BRAF mutation in colorectal cancer. Nat Genet 2006;38:787-793.

103 Nosho K, Irahara N, Shima K, et al. Comprehensive biostatistical analysis of $\mathrm{CpG}$ island methylator phenotype in colorectal cancer using a large population-based sample. PLoS ONE 2008;3:e3698.

104 The Cancer Genome Atlas Network. Comprehensive molecular characterization of human colon and rectal cancer. Nature 2012;487:330-337.

105 Gazin C, Wajapeyee N, Gobeil S, et al. An elaborate pathway required for Ras-mediated epigenetic silencing. Nature 2007;449:1073-1077.

106 Hinoue T, Weisenberger DJ, Pan F, et al. Analysis of the association between CIMP and BRAF in colorectal cancer by DNA methylation profiling. PLoS One 2009;4:e8357.

107 Lin H, Yamada Y, Nguyen S, et al. Suppression of intestinal neoplasia by deletion of Dnmt3b. Mol Cell Biol 2006;26:2976-2983.

108 Linhart HG, Lin H, Yamada Y, et al. Dnmt3b promotes tumorigenesis in vivo by gene-specific de novo methylation and transcriptional silencing. Genes Dev 2007;21:3110-3122.

109 Palakurthy RK, Wajapeyee N, Santra MK, et al. Epigenetic silencing of the RASSF1A tumor suppres- sor gene through HOXB3-mediated induction of DNMT3B expression. Mol Cell 2009;36:219-230.

110 Nosho K, Shima K, Irahara N, et al. DNMT3B expression might contribute to $\mathrm{CpG}$ island methylator phenotype in colorectal cancer. Clin Cancer Res 2009;15:3663-3671.

111 Ibrahim AE, Arends MJ, Silva AL, et al. Sequential DNA methylation changes are associated with DNMT3B overexpression in colorectal neoplastic progression. Gut 2011;60:499-508.

112 Steine EJ, Ehrich M, Bell GW, et al. Genes methylated by DNA methyltransferase $3 \mathrm{~b}$ are similar in mouse intestine and human colon cancer. J Clin Invest 2011;121:1748-1752.

113 Vaughn CP, Wilson AR, Samowitz WS. Quantitative evaluation of CpG island methylation in hyperplastic polyps. Mod Pathol 2010;23:151-156.

114 Huang CS, Farraye FA, Yang S, et al. The clinical significance of serrated polyps. Am J Gastroenterol 2011;106:229-240.

115 Snover DC. Update on the serrated pathway to colorectal carcinoma. Hum Pathol 2011;42:1-10.

116 Patil DT, Shadrach BL, Rybicki LA, et al. Proximal colon cancers and the serrated pathway: a systematic analysis of precursor histology and BRAF mutation status. Mod Pathol 2012;25:1423-1431.

117 Kriegl L, Neumann J, Vieth M, et al. Up and downregulation of $\mathrm{p} 16$ (Ink4a) expression in BRAF-mutated polyps/adenomas indicates a senescence barrier in the serrated route to colon cancer. Mod Pathol 2011;24:1015-1022.

118 Ogino S, Kawasaki T, Kirkner GJ, et al. CpG island methylator phenotype-low (CIMP-low) in colorectal cancer: possible associations with male sex and KRAS mutations. J Mol Diagn 2006;8:582-588.

119 Shen L, Toyota M, Kondo Y, et al. Integrated genetic and epigenetic analysis identifies three different subclasses of colon cancer. Proc Natl Acad Sci USA 2007;104:18654-18659.

120 Ogino S, Kawasaki T, Kirkner GJ, et al. Molecular correlates with MGMT promoter methylation and silencing support CpG island methylator phenotypelow (CIMP-low) in colorectal cancer. Gut 2007;56:1409-1416.

121 Barault L, Charon-Barra C, Jooste V, et al. Hypermethylator phenotype in sporadic colon cancer: study on a population-based series of 582 cases. Cancer Res 2008;68:8541-8546.

$122 \mathrm{Kim} \mathrm{JH}$, Shin SH, Kwon HJ, et al. Prognostic implications of $\mathrm{CpG}$ island hypermethylator phenotype in colorectal cancers. Virchows Arch 2009; 455:485-494.

123 Dahlin AM, Palmqvist R, Henriksson ML, et al. The role of the $\mathrm{CpG}$ island methylator phenotype in colorectal cancer prognosis depends on microsatellite instability screening status. Clin Cancer Res 2010; 16:1845-1855.

124 Van Guelpen B, Dahlin AM, Hultdin J, et al. Onecarbon metabolism and CpG island methylator phenotype status in incident colorectal cancer: a nested case-referent study. Cancer Causes Control 2010; 21:557-566

125 Tanaka N, Huttenhower C, Nosho K, et al. Novel application of structural equation modeling to correlation structure analysis of $\mathrm{CpG}$ island methylation in colorectal cancer. Am J Pathol 2010;177: 2731-2740. 
126 Karpinski P, Szmida E, Misiak B, et al. Assessment of three epigenotypes in colorectal cancer by combined bisulfite restriction analysis. Mol Carcinogen 2012;51:1003-1008.

127 Hinoue T, Weisenberger DJ, Lange CP, et al. Genomescale analysis of aberrant DNA methylation in colorectal cancer. Genome Res 2012;22:271-282.

128 Zlobec I, Bihl MP, Foerster A, et al. Stratification and prognostic relevance of Jass's molecular classification of colorectal cancer. Front Oncol 2012;2:7.

129 Imamura Y, Morikawa $\mathrm{T}$, Liao X, et al. Specific mutations in KRAS codons 12 and 13, and patient prognosis in 1075 BRAF-wild-type colorectal cancers. Clin Cancer Res 2012;18:4753-4763.

130 Kawasaki T, Ohnishi M, Nosho K, et al. CpG island methylator phenotype-low (CIMP-low) colorectal cancer shows not only few methylated CIMP-highspecific CpG islands, but also low-level methylation at individual loci. Mod Pathol 2008;21:245-255.

131 Yagi K, Akagi K, Hayashi $\mathrm{H}$, et al. Three DNA methylation epigenotypes in human colorectal cancer. Clin Cancer Res 2010;16:21-33.

132 Ogino S, Nosho K, Kirkner GJ, et al. CpG island methylator phenotype, microsatellite instability, BRAF mutation and clinical outcome in colon cancer. Gut 2009;58:90-96.

133 Liao X, Morikawa T, Lochhead P, et al. Prognostic role of PIK3CA mutation in colorectal cancer: cohort study and literature review. Clin Cancer Res 2012;18:2257-2268.

134 Whitehall VL, Rickman C, Bond CE, et al. Oncogenic PIK3CA mutations in colorectal cancers and polyps. Int J Cancer 2012;131:813-820.

135 Ogino S, Meyerhardt JA, Kawasaki T, et al. CpG island methylation, response to combination chemotherapy, and patient survival in advanced microsatellite stable colorectal carcinoma. Virchows Arch 2007;450:529-537.

136 Teodoridis JM, Hardie C, Brown R. CpG island methylator phenotype (CIMP) in cancer: Causes and implications. Cancer Lett 2008;268:177-186.

$137 \mathrm{Wu}$ C, Bekaii-Saab T. CpG island methylation, microsatellite instability, and BRAF mutations and their clinical application in the treatment of colon cancer. Chemother Res Pract 2012;2012:359041.

138 Jover R, Nguyen TP, Perez-Carbonell L, et al. 5Fluorouracil adjuvant chemotherapy does not increase survival in patients with $\mathrm{CpG}$ island methylator phenotype colorectal cancer. Gastroenterology 2011;140:1174-1181.

139 Van Rijnsoever M, Elsaleh H, Joseph D, et al. CpG island methylator phenotype is an independent predictor of survival benefit from 5-fluorouracil in stage III colorectal cancer. Clin Cancer Res 2003;9:2898-2903.

140 Wong JJ, Hawkins NJ, Ward RL, et al. Methylation of the 3p22 region encompassing MLH1 is representative of the $\mathrm{CpG}$ island methylator phenotype in colorectal cancer. Mod Pathol 2011;24:396-411.

141 Sanchez JA, Krumroy L, Plummer S, et al. Genetic and epigenetic classifications define clinical phenotypes and determine patient outcomes in colorectal cancer. Br J Surg 2009;96:1196-1204.

142 Yamauchi M, Morikawa T, Kuchiba A, et al. Assessment of colorectal cancer molecular features along bowel subsites challenges the conception of distinct dichotomy of proximal versus distal colorectum. Gut 2012;61:847-854.

143 Chirieac LR, Shen L, Catalano PJ, et al. Phenotype of microsatellite-stable colorectal carcinomas with $\mathrm{CpG}$ island methylation. Am J Surg Pathol 2005;29: 429-436.

144 Ogino S, Odze RD, Kawasaki T, et al. Correlation of pathologic features with $\mathrm{CpG}$ island methylator phenotype (CIMP) by quantitative DNA methylation analysis in colorectal carcinoma. Am J Surg Pathol 2006;30:1175-1183.

145 Kawasaki T, Ohnishi M, Suemoto Y, et al. WRN promoter methylation possibly connects mucinous differentiation, microsatellite instability and $\mathrm{CpG}$ island methylator phenotype in colorectal cancer. Mod Pathol 2008;21:150-158.

146 Kakar S, Deng G, Smyrk TC, et al. Loss of heterozygosity, aberrant methylation, BRAF mutation and KRAS mutation in colorectal signet ring cell carcinoma. Mod Pathol 2012;25:1040-1047.

147 Nosho K, Baba Y, Tanaka N, et al. Tumour-infiltrating T-cell subsets, molecular changes in colorectal cancer and prognosis: cohort study and literature review. J Pathol 2010;222:350-366.

148 Dahlin AM, Henriksson ML, Van Guelpen B, et al. Colorectal cancer prognosis depends on T-cell infiltration and molecular characteristics of the tumor. Mod Pathol 2011;24:671-682.

149 Ogino S, Nosho K, Irahara N, et al. Lymphocytic reaction to colorectal cancer is associated with longer survival, independent of lymph node count, microsatellite instability, and $\mathrm{CpG}$ island methylator phenotype. Clin Cancer Res 2009;15:6412-6420.

150 Ogino S, Brahmandam M, Kawasaki T, et al. Combined analysis of COX-2 and p53 expressions reveals synergistic inverse correlations with microsatellite instability and $\mathrm{CpG}$ island methylator phenotype in colorectal cancer. Neoplasia 2006;8:458-464.

151 Ogino S, Kawasaki T, Kirkner GJ, et al. Downregulation of p21 (CDKN1A/CIP1) is inversely associated with microsatellite instability and $\mathrm{CpG}$ island methylator phenotype (CIMP) in colorectal cancer. J Pathol 2006;210:147-154.

152 Ogino S, kawasaki T, Kirkner GJ, et al. Loss of nuclear p27 (CDKN1B/KIP1) in colorectal cancer is correlated with microsatellite instability and CIMP. Mod Pathol 2007;20:15-22.

153 Kawasaki T, Nosho K, Ohnishi M, et al. Correlation of beta-catenin localization with cyclooxygenase-2 expression and $\mathrm{CpG}$ island methylator phenotype (CIMP) in colorectal cancer. Neoplasia 2007;9: 569-577.

154 Samowitz WS, Slattery ML, Sweeney C, et al. APC mutations and other genetic and epigenetic changes in colon cancer. Mol Cancer Res 2007;5:165-170.

155 Nosho K, Shima K, Irahara N, et al. SIRT1 histone deacetylase expression is associated with microsatellite instability and CpG island methylator phenotype in colorectal cancer. Mod Pathol 2009;22:922-932.

156 Baba Y, Nosho K, Shima K, et al. PTGER2 overexpression in colorectal cancer is associated with microsatellite instability, independent of CpG island methylator phenotype. Cancer Epidemiol Biomarkers Prev 2010;19:822-831.

157 Ogino S, Kawasaki T, Nosho K, et al. LINE-1 hypomethylation is inversely associated with micro- 
satellite instability and $\mathrm{CpG}$ methylator phenotype in colorectal cancer. Int J Cancer 2008;122:2767-2773.

158 Baba Y, Nosho K, Shima K, et al. Relationship of CDX2 loss with molecular features and prognosis in colorectal cancer. Clin Cancer Res 2009;15: 4665-4673.

159 Zlobec I, Bihl M, Foerster A, et al. Comprehensive analysis of $\mathrm{CpG}$ island methylator phenotype (CIMP)high, -low, and -negative colorectal cancers based on protein marker expression and molecular features. J Pathol 2011;225:336-343.

160 Ogino S, Kawasaki T, Kirkner GJ, et al. 18q loss of heterozygosity in microsatellite stable colorectal cancer is correlated with $\mathrm{CpG}$ island methylator phenotype-negative (CIMP-0) and inversely with CIMP-low and CIMP-high. BMC Cancer 2007;7:72.

161 Goel A, Nagasaka T, Arnold CN, et al. The CpG island methylator phenotype and chromosomal instability are inversely correlated in sporadic colorectal cancer. Gastroenterology 2007;132:127-138.

162 Cheng YW, Pincas H, Bacolod MD, et al. CpG island methylator phenotype associates with low-degree chromosomal abnormalities in colorectal cancer. Clin Cancer Res 2008;14:6005-6013.

163 Kozlowska J, Karpinski P, Szmida E, et al. Assessment of chromosomal imbalances in CIMP-high and CIMPlow/CIMP-0 colorectal cancers. Tumour Biol 2012;33:1015-1019.

164 Morikawa T, Kuchiba A, Qian ZR, et al. Prognostic significance and molecular associations of tumor growth pattern in colorectal cancer. Ann Surg Oncol 2012;19:1944-1953.

165 Zlobec I, Bihl MP, Foerster A, et al. The impact of CpG island methylator phenotype and microsatellite instability on tumour budding in colorectal cancer. Histopathology 2012;61:777-787.

166 Ogino S, Shima K, Meyerhardt J, et al. Predictive and prognostic roles of BRAF mutation in stage III colon cancer: results from Intergroup Trial CALGB 89803. Clin Cancer Res 2012;18:890-900.

167 French AJ, Sargent DJ, Burgart LJ, et al. Prognostic significance of defective mismatch repair and BRAF V600E in patients with colon cancer. Clin Cancer Res 2008;14:3408-3415.

168 Samowitz WS, Sweeney C, Herrick J, et al. Poor survival associated with the BRAF V600E mutation in microsatellite-stable colon cancers. Cancer Res 2005;65:6063-6069.

169 Zlobec I, Bihl MP, Schwarb H, et al. Clinicopathological and protein characterization of BRAF- and K-RAS-mutated colorectal cancer and implications for prognosis. Int J Cancer 2010;127:367-380.

170 Roth AD, Tejpar S, Delorenzi M, et al. Prognostic role of KRAS and BRAF in stage II and III resected colon cancer: results of the translational study on the PETACC-3, EORTC 40993, SAKK 60-00 trial. J Clin Oncol 2010;28:466-474.

171 Souglakos J, Philips J, Wang R, et al. Prognostic and predictive value of common mutations for treatment response and survival in patients with metastatic colorectal cancer. Br J Cancer 2009;101: $465-472$.

172 Farina-Sarasqueta A, van Lijnschoten G, Moerland E, et al. The BRAF V600E mutation is an independent prognostic factor for survival in stage II and stage III colon cancer patients. Ann Oncol 2010;21: 2396-2402.
173 Ferracin M, Gafa R, Miotto E, et al. The methylator phenotype in microsatellite stable colorectal cancers is characterized by a distinct gene expression profile. J Pathol 2008;214:594-602.

174 Saridaki Z, Papadatos-Pastos D, Tzardi M, et al. BRAF mutations, microsatellite instability status and cyclin D1 expression predict metastatic colorectal patients' outcome. Br J Cancer 2010;102:1762-1768.

175 Kalady MF, Sanchez JA, Manilich E, et al. Divergent oncogenic changes influence survival differences between colon and rectal adenocarcinomas. Dis Colon Rectum 2009;52:1039-1045.

176 Popat S, Hubner R, Houlston RS. Systematic review of microsatellite instability and colorectal cancer prognosis. J Clin Oncol 2005;23:609-618.

177 Richman SD, Seymour MT, Chambers P, et al. KRAS and BRAF mutations in advanced colorectal cancer are associated with poor prognosis but do not preclude benefit from oxaliplatin or irinotecan: results from the MRC FOCUS trial. J Clin Oncol 2009;27:5931-5937.

178 Hutchins G, Southward K, Handley K, et al. Value of mismatch repair, KRAS, and BRAF mutations in predicting recurrence and benefits from chemotherapy in colorectal cancer. J Clin Oncol 2011;29: 1261-1270.

179 Price TJ, Hardingham JE, Lee CK, et al. Impact of KRAS and BRAF gene mutation status on outcomes from the Phase III AGITG MAX trial of capecitabine alone or in combination with bevacizumab and mitomycin in advanced colorectal cancer. J Clin Oncol 2011;29:2675-2682.

180 Phipps AI, Buchanan DD, Makar KW, et al. BRAF mutation status and survival after colorectal cancer diagnosis according to patient and tumor characteristics. Cancer Epidemiol Biomarkers Prev 2012;21: 1792-1798.

181 Gavin P, Colangelo LH, Fumagalli D, et al. Mutation profiling and microsatellite instability in stage II and III colon cancer: an assessment of their prognostic and oxaliplatin predictive value. Clin Cancer Res 2012;18:6531-6541.

182 Popovici V, Budinska E, Tejpar S, et al. Identification of a poor-prognosis BRAF-mutant-like population of patients with colon cancer. J Clin Oncol 2012;30:1288-1295.

183 Nosho K, Kure S, Irahara N, et al. A prospective cohort study shows unique epigenetic, genetic, and prognostic features of synchronous colorectal cancers. Gastroenterology 2009;137:1609-1620.e1603.

184 Konishi K, Shen L, Jelinek J, et al. Concordant DNA methylation in synchronous colorectal carcinomas. Cancer Prev Res (Philadelphia, PA) 2009;2: 814-822.

185 Gonzalo V, Lozano JJ, Munoz J, et al. Aberrant gene promoter methylation associated with sporadic multiple colorectal cancer. PLoS One 2010;5:e8777.

186 Leggett BA, Worthley DL. Synchronous colorectal cancer: not just bad luck? Gastroenterology 2009; 137:1559-1562.

187 Funkhouser WK, Lubin IM, Monzon FA, et al. Relevance, pathogenesis, and testing algorithm for mismatch repair-defective colorectal carcinomas: a report of the Association for Molecular Pathology. J Mol Diagn 2012;14:91-103.

188 Tournier B, Chapusot C, Courcet E, et al. Why do results conflict regarding the prognostic value of the 
methylation status in colon cancers? The role of the preservation method. BMC Cancer 2012;12:12.

189 Ang PW, Loh M, Liem N, et al. Comprehensive profiling of DNA methylation in colorectal cancer reveals subgroups with distinct clinicopathological and molecular features. BMC Cancer 2010;10:227.

190 Rawson JB, Bapat B. Epigenetic biomarkers in colorectal cancer diagnostics. Expert Rev Mol Diagn 2012;12:499-509.

191 Morikawa T, Shima K, Kuchiba A, et al. No evidence for interference of h\&e staining in DNA testing: usefulness of DNA extraction from h\&e-stained archival tissue sections. Am J Clin Pathol 2012;138: 122-129.

192 Ogino S, Kawasaki T, Brahmandam M, et al. Sensitive sequencing method for KRAS mutation detection by pyrosequencing. J Mol Diagn 2005;7:413-421.

193 Ogino S, Kawasaki T, Brahmandam M, et al. Precision and performance characteristics of bisulfite conversion and real-time PCR (MethyLight) for quantitative DNA methylation analysis. J Mol Diagn 2006;8: 209-217.

194 Irahara N, Nosho K, Baba Y, et al. Precision of pyrosequencing assay to measure LINE-1 methylation in colon cancer, normal colonic mucosa and peripheral blood cells. J Mol Diagn 2010;12:177-183.

195 Ogino S, Kawasaki T, Kirkner GJ, et al. Evaluation of markers for $\mathrm{CpG}$ island methylator phenotype (CIMP) in colorectal cancer by a large population-based sample. J Mol Diagn 2007;9:305-314.

196 Rosenberg AR, Skapek SX, Hawkins DS. The inconvenience of convenience cohorts: rhabdomyosarcoma and the PAX-FOXO1 biomarker. Cancer Epidemiol Biomarkers Prev 2012;21:1012-1018.

197 Ioannidis JP. Why most published research findings are false. PLoS Med 2005;2:e124.

198 Kitkumthorn N, Mutirangura A. Long interspersed nuclear element-1 hypomethylation in cancer: biology and clinical applications. Clin Epigenet 2012;2: 315-330.

199 Yang AS, Estecio MR, Doshi K, et al. A simple method for estimating global DNA methylation using bisulfite PCR of repetitive DNA elements. Nucleic Acids Res 2004;32:e38.

200 Frigola J, Sole X, Paz MF, et al. Differential DNA hypermethylation and hypomethylation signatures in colorectal cancer. Hum Mol Genet 2005;14:319-326.

201 Aporntewan C, Phokaew C, Piriyapongsa J, et al. Hypomethylation of intragenic LINE-1 represses transcription in cancer cells through AGO2. PLoS One 2011;6:e17934.

202 Wissing S, Munoz-Lopez M, Macia A, et al. Reprogramming somatic cells into iPS cells activates LINE-1 retroelement mobility. Hum Mol Genet 2012; 21:208-218.

203 Speek M. Antisense promoter of human L1 retrotransposon drives transcription of adjacent cellular genes. Mol Cell Biol 2001;21:1973-1985.

204 Peaston AE, Evsikov AV, Graber JH, et al. Retrotransposons regulate host genes in mouse oocytes and preimplantation embryos. Dev Cell 2004;7:597-606.

205 Faulkner GJ, Kimura Y, Daub CO, et al. The regulated retrotransposon transcriptome of mammalian cells. Nat Genet 2009;41:563-571.

206 Han JS, Szak ST, Boeke JD. Transcriptional disruption by the L1 retrotransposon and implications for mammalian transcriptomes. Nature 2004;429:268-274.
207 Yamada Y, Jackson-Grusby L, Linhart H, et al. Opposing effects of DNA hypomethylation on intestinal and liver carcinogenesis. Proc Natl Acad Sci USA 2005;102:13580-13585.

208 Howard G, Eiges R, Gaudet F, et al. Activation and transposition of endogenous retroviral elements in hypomethylation induced tumors in mice. Oncogene 2008;27:404-408.

209 Estecio MR, Gharibyan V, Shen L, et al. LINE-1 hypomethylation in cancer is highly variable and inversely correlated with microsatellite instability. PLoS One 2007;2:e399.

210 Baba Y, Huttenhower C, Nosho K, et al. Epigenomic diversity of colorectal cancer indicated by LINE-1 methylation in a database of 869 tumors. Mol Cancer 2010;9:125.

211 Bae JM, Shin S, Kwon H, et al. ALU and LINE-1 hypomethylations in multistep gastric carcinogenesis and their prognostic implications. Int $\mathrm{J}$ Cancer 2012;131:1323-1331.

212 Igarashi S, Suzuki H, Niinuma T, et al. A novel correlation between LINE-1 hypomethylation and the malignancy of gastrointestinal stromal tumors. Clin Cancer Res 2010;16:5114-5123.

213 Pattamadilok J, Huapai N, Rattanatanyong $\mathrm{P}$, et al. LINE-1 hypomethylation level as a potential prognostic factor for epithelial ovarian cancer. Int J Gynecol Cancer 2008;18:711-717.

214 Roman-Gomez J, Jimenez-Velasco A, Agirre X, et al. Promoter hypomethylation of the LINE-1 retrotransposable elements activates sense/antisense transcription and marks the progression of chronic myeloid leukemia. Oncogene 2005;24:7213-7223.

215 Hoshimoto S, Kuo CT, Chong KK, et al. AIM1 and LINE-1 epigenetic aberrations in tumor and serum relate to melanoma progression and disease outcome. J Invest Dermatol 2012;132:1689-1697.

216 Ogino S, Nosho K, Kirkner GJ, et al. A cohort study of tumoral LINE-1 hypomethylation and prognosis in colon cancer. J Natl Cancer Inst 2008;100: 1734-1738.

217 Ahn JB, Chung WB, Maeda O, et al. DNA methylation predicts recurrence from resected stage III proximal colon cancer. Cancer 2011;117:1847-1854.

218 Rhee YY, Kim MJ, Bae JM, et al. Clinical outcomes of patients with microsatellite-unstable colorectal carcinomas depend on L1 methylation level. Ann Surg Oncol 2012;19:3441-3448.

219 Yegnasubramanian S, Haffner MC, Zhang Y, et al. DNA hypomethylation arises later in prostate cancer progression than $\mathrm{CpG}$ island hypermethylation and contributes to metastatic tumor heterogeneity. Cancer Res 2008;68:8954-8967.

220 Choi IS, Estecio MR, Nagano Y, et al. Hypomethylation of LINE-1 and Alu in well-differentiated neuroendocrine tumors (pancreatic endocrine tumors and carcinoid tumors). Mod Pathol 2007;20:802-810.

221 Sunami E, de Maat M, Vu A, et al. LINE-1 hypomethylation during primary colon cancer progression. PLoS One 2011;6:e18884.

222 Ogino S, Nosho K, Irahara N, et al. Prognostic significance and molecular associations of $18 \mathrm{q}$ loss of heterozygosity: a cohort study of microsatellite stable colorectal cancers. J Clin Oncol 2009;26: 5713-5720.

223 Lochhead P, Imamura Y, Morikawa T, et al. Insulinlike growth factor 2 messenger RNA binding protein 3 
(IGF2BP3) is a marker of unfavourable prognosis in colorectal cancer. Eur J Cancer 2012;48:3405-3413.

224 Baba Y, Nosho K, Shima K, et al. Hypomethylation of the IGF2 DMR in colorectal tumors, detected by bisulfite pyrosequencing, is associated with poor prognosis. Gastroenterology 2010;139:1855-1864.

225 Ito Y, Koessler T, Ibrahim AE, et al. Somatically acquired hypomethylation of IGF2 in breast and colorectal cancer. Hum Mol Genet 2008;17:2633-2643.

226 Antelo M, Balaguer F, Shia J, et al. A high degree of LINE-1 hypomethylation is a unique feature of earlyonset colorectal cancer. PLoS One 2012;7:e45357.

227 Goel A, Xicola RM, Nguyen TP, et al. Aberrant DNA methylation in hereditary nonpolyposis colorectal cancer without mismatch repair deficiency. Gastroenterology 2010;138:1854-1862.

228 Ogino S, Nishihara R, Lochhead P, et al. Prospective study of family history and colorectal cancer risk by tumor LINE-1 methylation level. J Natl Cancer Inst 2013 (in press).

229 Carmona FJ, Villanueva A, Vidal A, et al. Epigenetic disruption of cadherin-11 in human cancer metastasis. J Pathol 2012;228:230-240.

230 Ogino S, Meyerhardt JA, Irahara N, et al. KRAS mutation in stage III colon cancer and clinical outcome following intergroup trial CALGB 89803. Clin Cancer Res 2009;15:7322-7329.

231 Lievre A, Blons H, Laurent-Puig P. Oncogenic mutations as predictive factors in colorectal cancer. Oncogene 2010;29:3033-3043.

232 Myers MB, Wang Y, McKim KL, et al. Hotspot oncomutations: implications for personalized cancer treatment. Expert Rev Mol Diagn 2012;12:603-620.

233 Voutsina A, Tzardi M, Kalikaki A, et al. Combined analysis of KRAS and PIK3CA mutations, MET and PTEN expression in primary tumors and corresponding metastases in colorectal cancer. Mod Pathol 2012.

234 Bond CE, Umapathy A, Buttenshaw RL, et al. Chromosomal Instability in BRAF mutant, microsatellite stable colorectal cancers. PLoS One 2012;7:e47483

235 Adams MD, Veigl ML, Wang Z, et al. Global mutational profiling of formalin-fixed human colon cancers from a pathology archive. Mod Pathol 2012; 25:1599-1608.

236 Esteller M, Risques RA, Toyota M, et al. Promoter hypermethylation of the DNA repair gene $\mathrm{O}(6)$ methylguanine-DNA methyltransferase is associated with the presence of $\mathrm{G}: \mathrm{C}$ to $\mathrm{A}: \mathrm{T}$ transition mutations in p53 in human colorectal tumorigenesis. Cancer Res 2001;61:4689-4692.

237 Esteller M, Toyota M, Sanchez-Cespedes M, et al. Inactivation of the DNA repair gene O6-methylguanine-DNA methyltransferase by promoter hypermethylation is associated with $G$ to $A$ mutations in K-ras in colorectal tumorigenesis. Cancer Res 2000;60:2368-2371.

238 Halford S, Rowan A, Sawyer E, et al. O6-methylguanine methyltransferase in colorectal cancers: detection of mutations, loss of expression, and weak association with G:C $>$ A:T transitions. Gut 2005;54:797-802.

239 Nosho K, Kawasaki T, Ohnishi M, et al. PIK3CA mutation in colorectal cancer: relationship with genetic and epigenetic alterations. Neoplasia 2008; 10:534-541.
240 Suehiro Y, Wong CW, Chirieac LR, et al. Epigeneticgenetic interactions in the APC/WNT, RAS/RAF, and P53 pathways in colorectal carcinoma. Clin Cancer Res 2008;14:2560-2569.

241 Shima K, Morikawa T, Baba Y, et al. MGMT promoter methylation, loss of expression and prognosis in 855 colorectal cancers. Cancer Causes Control 2011;22:301-309.

242 de Vogel S, Weijenberg MP, Herman JG, et al. MGMT and MLH1 promoter methylation versus APC, KRAS and BRAF gene mutations in colorectal cancer: indications for distinct pathways and sequence of events. Ann Oncol 2009;20:1216-1222.

243 Timmermann B, Kerick M, Roehr C, et al. Somatic mutation profiles of MSI and MSS colorectal cancer identified by whole exome next generation sequencing and bioinformatics analysis. PLoS One 2010;5:e15661.

244 Shah SN, Hile SE, Eckert KA. Defective mismatch repair, microsatellite mutation bias, and variability in clinical cancer phenotypes. Cancer Res 2010;70: 431-435.

245 Dulak AM, Schumacher S, van Lieshout J, et al. Gastrointestinal adenocarcinomas of the esophagus, stomach and colon exhibit distinct patterns of genome instability and oncogenesis. Cancer Res 2012;72:4383-4393.

246 Donehower LA, Creighton CJ, Schultz N, et al. MLH1silenced and non-silenced subgroups of hypermutated colorectal carcinomas have distinct mutational landscapes. J Pathol 2013;229:99-110.

247 Nosho K, Kawasaki T, Chan AT, et al. Cyclin D1 is frequently overexpressed in microsatellite unstable colorectal cancer, independent of CpG island methylator phenotype. Histopathology 2008;53:588-598.

248 Shima K, Nosho K, Baba Y, et al. Prognostic significance of CDKN2A (p16) promoter methylation and loss of expression in 902 colorectal cancers: cohort study and literature review. Int J Cancer 2011;128:1080-1094.

249 Belt EJ, Brosens RP, Delis-van Diemen PM, et al. Cell cycle proteins predict recurrence in stage II and III colon cancer. Ann Surg Oncol 2012;19:S682-S692.

$250 \mathrm{Gu} \mathrm{H}$, Bock C, Mikkelsen TS, et al. Genome-scale DNA methylation mapping of clinical samples at single-nucleotide resolution. Nat Methods 2010;7: 133-136.

251 Kibriya MG, Raza M, Jasmine F, et al. A genome-wide DNA methylation study in colorectal carcinoma. BMC Med Genomics 2011;4:50.

252 Jasmine F, Rahaman R, Roy S, et al. Interpretation of genome-wide infinium methylation data from ligated DNA in formalin-fixed, paraffin-embedded paired tumor and normal tissue. BMC Res Notes 2012;5:117.

253 Samowitz WS, Albertsen $\mathrm{H}$, Sweeney C, et al. Association of smoking, $\mathrm{CpG}$ island methylator phenotype, and V600E BRAF mutations in colon cancer. J Natl Cancer Inst 2006;98:1731-1738.

254 Curtin K, Samowitz WS, Wolff RK, et al. Somatic alterations, metabolizing genes and smoking in rectal cancer. Int J Cancer 2009;125:158-164.

255 Limsui D, Vierkant RA, Tillmans LS, et al. Cigarette smoking and colorectal cancer risk by molecularly defined subtypes. J Natl Cancer Inst 2010;102: 1012-1022. 
256 Nishihara R, Morikawa T, Kuchiba A, et al. A prospective study of duration of smoking cessation and colorectal cancer risk by epigenetics-related tumor classification. Am J Epidemiol 2013 (in press).

257 Poynter JN, Haile RW, Siegmund KD, et al. Associations between smoking, alcohol consumption, and colorectal cancer, overall and by tumor microsatellite instability status. Cancer Epidemiol Biomarkers Prev 2009;18:2745-2750.

258 Lindor NM, Yang P, Evans I, et al. Alpha-1-antitrypsin deficiency and smoking as risk factors for mismatch repair deficient colorectal cancer: A study from the colon cancer family registry. Mol Genet Metab 2010;99:157-159.

259 Eaton AM, Sandler R, Carethers JM, et al. 5,10Methylenetetrahydrofolate reductase 677 and 1298 polymorphisms, folate intake, and microsatellite instability in colon cancer. Cancer Epidemiol Biomarkers Prev 2005;14:2023-2029.

260 Chia VM, Newcomb PA, Bigler J, et al. Risk of microsatellite-unstable colorectal cancer is associated jointly with smoking and nonsteroidal anti-inflammatory drug use. Cancer Res 2006;66:6877-6883.

261 Rozek LS, Herron CM, Greenson JK, et al. Smoking, gender, and ethnicity predict somatic BRAF mutations in colorectal cancer. Cancer Epidemiol Biomarkers Prev 2010;19:838-843.

262 Russo AL, Thiagalingam A, Pan H, et al. Differential DNA hypermethylation of critical genes mediates the stage-specific tobacco smoke-induced neoplastic progression of lung cancer. Clin Cancer Res 2005;11:2466-2470.

263 Vaissiere T, Hung RJ, Zaridze D, et al. Quantitative analysis of DNA methylation profiles in lung cancer identifies aberrant DNA methylation of specific genes and its association with gender and cancer risk factors. Cancer Res 2009;69:243-252.

264 Ulrich CM, Potter JD. Folate and cancer-timing is everything. JAMA 2007;297:2408-2409.

265 Carroll C, Cooper K, Papaioannou D, et al. Metaanalysis: folic acid in the prevention of colorectal adenomas and the chemoprevention of colorectal cancer. Aliment Pharmacol Ther 2010;31:708-718.

266 Cole BF, Baron JA, Sandler RS, et al. Folic acid for the prevention of colorectal adenomas: a randomized clinical trial. JAMA 2007;297:2351-2359.

267 Kadaveru K, Protiva P, Greenspan EJ, et al. Dietary methyl donor depletion protects against intestinal tumorigenesis in ApcMin/ + mice. Cancer Prev Res (Philadelphia) 2012;5:911-920.

268 Schaible TD, Harris RA, Dowd SE, et al. Maternal methyl-donor supplementation induces prolonged murine offspring colitis susceptibility in association with mucosal epigenetic and microbiomic changes. Hum Mol Genet 2011;20:1687-1696.

269 Kim YI, Pogribny IP, Salomon RN, et al. Exon-specific DNA hypomethylation of the p53 gene of rat colon induced by dimethylhydrazine. Modulation by dietary folate. Am J Pathol 1996;149:1129-1137.

270 Kawakami K, Ruszkiewicz A, Bennett G, et al. The folate pool in colorectal cancers is associated with DNA hypermethylation and with a polymorphism in methylenetetrahydrofolate reductase. Clin Cancer Res 2003;9:5860-5865.

271 van Engeland M, Weijenberg MP, Roemen GM, et al. Effects of dietary folate and alcohol intake on promoter methylation in sporadic colorectal cancer: the Netherlands Cohort Study on diet and cancer. Cancer Res 2003;63:3133-3137.

272 Schernhammer ES, Giovannucci E, Baba Y, et al. B vitamins, methionine and alcohol intake and risk of colon cancer in relation to BRAF mutation and CpG island methylator phenotype (CIMP). PLoS One 2011;6:e21102.

273 Razzak AA, Oxentenko AS, Vierkant RA, et al. Alcohol intake and colorectal cancer risk by molecularly defined subtypes in a prospective study of older women. Cancer Prev Res (Philadelphia) 2011;4: 2035-2043.

274 Slattery ML, Curtin K, Sweeney C, et al. Diet and lifestyle factor associations with $\mathrm{CpG}$ island methylator phenotype and BRAF mutations in colon cancer. Int J Cancer 2007;120:656-663.

275 Curtin K, Samowitz WS, Ulrich CM, et al. Nutrients in folate-mediated, one-carbon metabolism and the risk of rectal tumors in men and women. Nutr Cancer 2011;63:357-366.

276 Curtin K, Ulrich CM, Samowitz WS, et al. Candidate pathway polymorphisms in one-carbon metabolism and risk of rectal tumor mutations. Int $\mathrm{J}$ Mol Epidemiol Genet 2011;2:1-8.

277 Razzak AA, Oxentenko AS, Vierkant RA, et al. Associations between intake of folate and related micronutrients with molecularly defined colorectal cancer risks in the Iowa Women's Health Study. Nutr Cancer 2012;64:899-910.

278 de Vogel S, Wouters KA, Gottschalk RW, et al. Genetic variants of methyl metabolizing enzymes and epigenetic regulators: associations with promoter $\mathrm{CpG}$ island hypermethylation in colorectal cancer. Cancer Epidemiol Biomarkers Prev 2009;18:3086-3096.

279 Curtin K, Slattery ML, Ulrich CM, et al. Genetic polymorphisms in one-carbon metabolism: associations with $\mathrm{CpG}$ island methylator phenotype (CIMP) in colon cancer and the modifying effects of diet. Carcinogenesis 2007;28:1672-1679.

280 Hazra A, Fuchs CS, Kawasaki T, et al. Germline polymorphisms in the one-carbon metabolism pathway and DNA methylation in colorectal cancer. Cancer Causes Control 2010;21:331-345.

281 Linhart HG, Troen A, Bell GW, et al. Folate deficiency induces genomic uracil misincorporation and hypomethylation but does not increase DNA point mutations. Gastroenterology 2009;136:e223.

282 Hervouet E, Debien E, Campion L, et al. Folate supplementation limits the aggressiveness of glioma via the remethylation of DNA repeats element and genes governing apoptosis and proliferation. Clin Cancer Res 2009;15:3519-3529.

283 Wasson GR, McGlynn AP, McNulty H, et al. Global DNA and p53 region-specific hypomethylation in human colonic cells is induced by folate depletion and reversed by folate supplementation. J Nutr 2006;136:2748-2753.

284 Schernhammer ES, Ogino S, Fuchs CS. Folate intake and risk of colon cancer in relation to p53 status. Gastroenterology 2008;135:770-780.

285 Schernhammer ES, Giovannucci E, Kawasaki T, et al. Dietary folate, alcohol, and B vitamins in relation to LINE-1 hypomethylation in colon cancer. Gut 2010;59:794-799.

286 Figueiredo JC, Grau MV, Wallace K, et al. Global DNA hypomethylation (LINE-1) in the normal colon and lifestyle characteristics and dietary and genetic 
factors. Cancer Epidemiol Biomarkers Prev 2009; 18:1041-1049.

287 Pufulete M, Al-Ghnaniem R, Khushal A, et al. Effect of folic acid supplementation on genomic DNA methylation in patients with colorectal adenoma. Gut 2005;54:648-653.

288 Vrieling A, Kampman E. The role of body mass index, physical activity, and diet in colorectal cancer recurrence and survival: a review of the literature. Am J Clin Nutr 2010;92:471-490.

289 Ballard-Barbash R, Friedenreich CM, Courneya KS, et al. Physical activity, biomarkers, and disease outcomes in cancer survivors: a systematic review. J Natl Cancer Inst 2012;104:815-840.

290 Jeon JY, Meyerhardt JA. Energy in and energy out: what matters for survivors of colorectal cancer? J Clin Oncol 2012;30:7-10.

291 Giovannucci EL. Physical activity as a standard cancer treatment. J Natl Cancer Inst 2012;104: 797-799.

292 Clague J, Bernstein L. Physical activity and cancer. Curr Oncol Rep 2012;14:550-558.

293 Betof AS, Dewhirst MW, Jones LW. Effects and potential mechanisms of exercise training on cancer progression: a translational perspective. Brain Behav Immun 2013 (in press).

294 Hughes LA, van den Brandt PA, de Bruine AP, et al. Early life exposure to famine and colorectal cancer risk: a role for epigenetic mechanisms. PLoS One 2009;4:e7951.

295 Slattery ML, Curtin K, Anderson K, et al. Associations between cigarette smoking, lifestyle factors, and microsatellite instability in colon tumors. J Natl Cancer Inst 2000;92:1831-1836.

296 Satia JA, Keku T, Galanko JA, et al. Diet, lifestyle, and genomic instability in the North Carolina Colon Cancer Study. Cancer Epidemiol Biomarkers Prev 2005;14:429-436.

297 Campbell PT, Jacobs ET, Ulrich CM, et al. Casecontrol study of overweight, obesity, and colorectal cancer risk, overall and by tumor microsatellite instability status. J Natl Cancer Inst 2010;102: 391-400.

298 Kuchiba A, Morikawa T, Yamauchi M, et al. Body mass index and risk of colorectal cancer according to fatty acid synthase expression in the Nurses' Health Study. J Natl Cancer Inst 2012;104:415-420.

299 Uddin S, Hussain AR, Ahmed M, et al. High prevalence of fatty acid synthase expression in colorectal cancers in middle eastern patients and its potential role as a therapeutic target. Am J Gastroenterol 2009;104:1790-1801.

300 Migita T, Ruiz S, Fornari A, et al. Fatty acid synthase: a metabolic enzyme and candidate oncogene in prostate cancer. J Natl Cancer Inst 2009;101: 519-532.

301 Ogino S, Kawasaki T, Ogawa A, et al. Fatty acid synthase overexpression in colorectal cancer is associated with microsatellite instability, independent of $\mathrm{CpG}$ island methylator phenotype. Hum Pathol 2007;38:842-849.

302 Baba Y, Nosho K, Shima K, et al. Prognostic significance of AMP-activated protein kinase expression and modifying effect of MAPK3/1 in colorectal cancer. Br J Cancer 2010;103:1025-1033.

303 Ogino S, Nosho K, Baba Y, et al. A cohort study of STMN1 expression in colorectal cancer: body mass index and prognosis. Am J Gastroenterol 2009;104: 2047-2056.

304 Ogino S, Nosho K, Shima K, et al. P21 expression in colon cancer and modifying effects of patient age and body mass index on prognosis. Cancer Epidemiol Biomarkers Prev 2009;18:2513-2521.

305 Ogino S, Shima K, Nosho K, et al. A cohort study of p27 localization in colon cancer, body mass index, and patient survival. Cancer Epidemiol Biomarkers Prev 2009;18:1849-1858.

306 Meyerhardt JA, Ogino S, Kirkner GJ, et al. Interaction of molecular markers and physical activity on mortality in patients with colon cancer. Clin Cancer Res 2009;15:5931-5936.

307 Li L, Lee KM, Han W, et al. Estrogen and progesterone receptor status affect genome-wide DNA methylation profile in breast cancer. Hum Mol Genet 2010;19: 4273-4277.

$308 \mathrm{Wu} \mathrm{AH}$, Siegmund KD, Long TI, et al. Hormone therapy, DNA methlyation and colon cancer. Carcinogenesis 2010;31:1060-1067.

309 Lin JH, Morikawa T, Chan AT, et al. Postmenopausal hormone therapy is associated with a reduced risk of colorectal cancer lacking CDKN1A expression. Cancer Res 2012;72:3020-3028.

310 Kure S, Nosho K, Baba Y, et al. Vitamin D receptor expression is associated with PIK3CA and KRAS mutations in colorectal cancer. Cancer Epidemiol Biomarkers Prev 2009;18:2765-2772.

311 Pereira F, Barbachano A, Silva J, et al. KDM6B/JMJD3 histone demethylase is induced by vitamin $\mathrm{D}$ and modulates its effects in colon cancer cells. Hum Mol Genet 2011;20:4655-4665.

312 Blumberg R, F Powrie. Microbiota disease, and back to health: a metastable journey. Sci Transl Med 2012;4:137rv137.

313 Larsson E, Tremaroli V, Lee YS, et al. Analysis of gut microbial regulation of host gene expression along the length of the gut and regulation of gut microbial ecology through MyD88. Gut 2012;61:1124-1131.

314 Ly NP, Litonjua A, Gold DR, et al. Gut microbiota, probiotics, and vitamin D: interrelated exposures influencing allergy, asthma, and obesity? J Allergy Clin Immunol 2011;127:1087-1094; quiz 1095-1086.

315 Allen M, Louise JJ. Jekyll and Hyde: the role of the microenvironment on the progression of cancer. J Pathol 2011;223:162-176.

316 Fridman WH, Pages F, Sautes-Fridman C, et al. The immune contexture in human tumours: impact on clinical outcome. Nat Rev Cancer 2012;12:298-306.

317 Ding SZ, Goldberg JB, Hatakeyama M. Helicobacter pylori infection, oncogenic pathways and epigenetic mechanisms in gastric carcinogenesis. Fut Oncol 2010;6:851-862.

318 Peterson AJ, Menheniott TR, O'Connor L, et al. Helicobacter pylori infection promotes methylation and silencing of trefoil factor 2, leading to gastric tumor development in mice and humans. Gastroenterology 2010;139:2005-2017.

319 Bebek G, Bennett KL, Funchain P, et al. Microbiomic subprofiles and MDR1 promoter methylation in head and neck squamous cell carcinoma. Hum Mol Genet 2012;21:1557-1565.

320 Fernandez AF, Esteller M. Viral epigenomes in human tumorigenesis. Oncogene 2010;29:1405-1420.

321 Fernandez AF, Rosales C, Lopez-Nieva P, et al. The dynamic DNA methylomes of double-stranded DNA 
viruses associated with human cancer. Genome Res 2009;19:438-451.

322 De-Castro Arce J, Gockel-Krzikalla E, Rosl F. Silencing of multi-copy HPV16 by viral self-methylation and chromatin occlusion: a model for epigenetic virus-host interaction. Hum Mol Genet 2012;21: 1693-1705.

323 Hino R, Uozaki H, Murakami N, et al. Activation of DNA methyltransferase 1 by EBV latent membrane protein $2 \mathrm{~A}$ leads to promoter hypermethylation of PTEN gene in gastric carcinoma. Cancer Res 2009; 69:2766-2774.

324 Goel A, Li MS, Nagasaka T, et al. Association of JC virus T-antigen expression with the methylator phenotype in sporadic colorectal cancers. Gastroenterology 2006;130:1950-1961.

325 Nosho K, Shima K, Kure S, et al. JC virus T-antigen in colorectal cancer is associated with p53 expression and chromosomal instability, independent of CpG island methylator phenotype. Neoplasia 2009;11: 87-95.

326 Karpinski P, Myszka A, Ramsey D, et al. Detection of viral DNA sequences in sporadic colorectal cancers in relation to $\mathrm{CpG}$ island methylation and methylator phenotype. Tumour Biol 2011;32:653-659.

327 Wang D, Dubois RN. The role of COX-2 in intestinal inflammation and colorectal cancer. Oncogene 2010; 29:781-788.

328 Grivennikov SI, Greten FR, Karin M. Immunity, inflammation, and cancer. Cell 2010;140:883-899.

329 Wang D, Xia D, DuBois RN. The crosstalk of PTGS2 and EGF signaling pathways in colorectal cancer. Cancers 2011;3:3894-3908.

330 Wang D, Dubois RN. Associations between obesity and cancer: the role of fatty acid synthase. J Natl Cancer Inst 2012;104:343-345.

331 Girnun G. PPARG: a new independent marker for colorectal cancer survival. Gastroenterology 2009; 136:1157-1160.

332 Kanai Y, Hirohashi S. Alterations of DNA methylation associated with abnormalities of DNA methyltransferases in human cancers during transition from a precancerous to a malignant state. Carcinogenesis 2007;28:2434-2442.

333 O’Hagan HM, Wang W, Sen S, et al. Oxidative damage targets complexes containing DNA methyltransferases, SIRT1, and polycomb members to promoter CpG islands. Cancer Cell 2011;20:606-619.

334 Brigati C, Banelli B, di Vinci A, et al. Inflammation, HIF-1, and the epigenetics that follows. Mediators Inflamm 2010;2010:263914.

335 Xia D, Wang D, Kim SH, et al. Prostaglandin E(2) promotes intestinal tumor growth via DNA methylation. Nat Med 2012;18:224-226.

336 Kellermayer R, Balasa A, Zhang W, et al. Epigenetic maturation in colonic mucosa continues beyond infancy in mice. Hum Mol Genet 2010;19:2168-2176.

337 Chan AT, Ogino S, Fuchs CS. Aspirin and the risk of colorectal cancer in relation to the expression of COX-2. N Engl J Med 2007;356:2131-2142.

338 Ogino S, Kirkner GJ, Nosho K, et al. Cyclooxygenase-2 expression is an independent predictor of poor prognosis in colon cancer. Clin Cancer Res 2008; 14:8221-8227.

339 Yamauchi M, Lochhead P, Morikawa T, et al. Colorectal cancer: a tale of two sides or a continuum? Gut 2012;61:794-797.
340 Li X, Leblanc J, Truong A, et al. A metaproteomic approach to study human-microbial ecosystems at the mucosal luminal interface. PLoS One 2011;6: $\mathrm{e} 26542$.

341 Edin S, Wikberg ML, Dahlin AM, et al. The distribution of macrophages with a $\mathrm{m} 1$ or $\mathrm{m} 2$ phenotype in relation to prognosis and the molecular characteristics of colorectal cancer. PLoS One 2012;7:e47045.

342 Cortese R, Kwan A, Lalonde E, et al. Epigenetic markers of prostate cancer in plasma circulating DNA. Hum Mol Genet 2012;21:3619-3631.

343 Bollati V, Baccarelli A, Hou L, et al. Changes in DNA methylation patterns in subjects exposed to low-dose benzene. Cancer Res 2007;67:876-880.

344 Terry MB, Delgado-Cruzata L, Vin-Raviv N, et al. DNA methylation in white blood cells: association with risk factors in epidemiologic studies. Epigenetics 2011;6:828-837.

345 Mirabello L, Savage SA, Korde L, et al. LINE-1 methylation is inherited in familial testicular cancer kindreds. BMC Med Genet 2010;11:77.

$346 \mathrm{Wu}$ HC, Delgado-Cruzata L, Flom JD, et al. Global methylation profiles in DNA from different blood cell types. Epigenetics 2011;6:76-85.

$347 \mathrm{Wu}$ HC, John EM, Ferris JS, et al. Global DNA methylation levels in girls with and without a family history of breast cancer. Epigenetics 2011;6:29-33.

348 Breitling LP, Yang R, Korn B, et al. Tobacco-smokingrelated differential DNA methylation: $27 \mathrm{~K}$ discovery and replication. Am J Hum Genet 2011;88:450-457.

349 van Bemmel D, Lenz P, Liao LM, et al. Correlation of LINE-1 methylation levels in patient-matched buffy coat, serum, buccal cell, and bladder tumor tissue DNA samples. Cancer Epidemiol Biomarkers Prev 2012;21:1143-1148.

350 Breton CV, Byun HM, Wenten M, et al. Prenatal tobacco smoke exposure affects global and genespecific DNA methylation. Am J Respir Crit Care Med 2009;180:462-467.

351 Breton CV, Salam MT, Wang X, et al. Particulate matter, DNA methylation in nitric oxide synthase, and childhood respiratory disease. Environ Health Perspect 2012;120:1320-1326.

352 Iacopetta B, Grieu F, Phillips M, et al. Methylation levels of LINE-1 repeats and CpG island loci are inversely related in normal colonic mucosa. Cancer Sci 2007;98:1454-1460.

353 Liu J, Hesson LB, Meagher AP, et al. Relative distribution of folate species is associated with global DNA methylation in human colorectal mucosa. Cancer Prev Res (Philadelphia) 2012;5:921-929.

354 Buda A, De Bona M, Dotti I, et al. Prevalence of different subtypes of serrated polyps and risk of synchronous advanced colorectal neoplasia in average-risk population undergoing first-time colonoscopy. Clin Transl Gasntroenterol 2012;3:e6.

355 Hunter DJ. Lessons from genome-wide association studies for epidemiology. Epidemiology 2012;23: 363-367.

356 Spain SL, Carvajal-Carmona LG, Howarth KM, et al. Refinement of the associations between risk of colorectal cancer and polymorphisms on chromosomes $1 \mathrm{q} 41$ and 12q13.13. Hum Mol Genet 2012;21: 934-946.

357 Price AL, Zaitlen NA, Reich D, et al. New approaches to population stratification in genome-wide association studies. Nat Rev Genet 2010;11:459-463. 
358 Thomas D. Gene-environment-wide association studies: emerging approaches. Nat Rev Genet 2010;11:259-272.

359 Hutter CM, Chang-Claude J, Slattery ML, et al. Characterization of gene-environment interactions for colorectal cancer susceptibility loci. Cancer Res 2012;72:2036-2044.

360 On beyond GWAS. Nat Genet 2010;42:551.

361 Ghosh A, Hartge P, Purdue MP, et al. Assessing disease risk in genome-wide association studies using family history. Epidemiology 2012;23:616-622.

362 Freedman ML, Monteiro AN, Gayther SA, et al. Principles for the post-GWAS functional characterization of cancer risk loci. Nat Genet 2011;43: $513-518$

363 Tuupanen S, Turunen M, Lehtonen $\mathrm{R}$, et al. The common colorectal cancer predisposition SNP rs6983267 at chromosome 8q24 confers potential to enhanced Wnt signaling. Nat Genet 2009;41:885-890.

364 Gruber SB, Moreno V, Rozek LS, et al. Genetic variation in 8q24 associated with risk of colorectal cancer. Cancer Biol Ther 2007;6:1143-1147.

365 Slattery ML, Herrick J, Curtin K, et al. Increased risk of colon cancer associated with a genetic polymorphism of SMAD7. Cancer Res 2010;70:1479-1485.

366 Garcia-Albeniz X, Nan H, Valeri L, et al. Phenotypic and tumor molecular characterization of colorectal cancer in relation to a susceptibility SMAD7 variant associated with survival. Carcinogenesis 2013 (in press).

367 Rakyan VK, Down TA, Balding DJ, et al. Epigenomewide association studies for common human diseases. Nat Rev Genet 2011;12:529-541.

368 Heijmans BT, Mill J. Commentary: the seven plagues of epigenetic epidemiology. Int J Epidemiol 2012;41: 74-78.

369 Febbo PG, Ladanyi M, Aldape KD, et al. NCCN Task Force report: evaluating the clinical utility of tumor markers in oncology. J Natl Compr Canc Netw 2011;9((Suppl 5)):S1-S32; quiz S33.

370 Khoury MJ, Gwinn M, Ioannidis JP. The emergence of translational epidemiology: from scientific discovery to population health impact. Am J Epidemiol 2010; 172:517-524.

371 Butler D. Translational research: crossing the valley of death. Nature 2008;453:840-842.

372 Colditz GA, Winn DM. Criteria for the evaluation of large cohort studies: an application to the nurses' health study. J Natl Cancer Inst 2008;100:918-925.

373 Colditz GA, Hankinson SE. The Nurses' Health Study: lifestyle and health among women. Nat Rev Cancer 2005;5:388-396.

374 Robison LL, Armstrong GT, Boice JD, et al. The Childhood Cancer Survivor Study: A National Cancer Institute-supported resource for outcome and intervention research. J Clin Oncol 2009;27: 2308-2318.

375 Colditz GA. Ensuring long-term sustainability of existing cohorts remains the highest priority to inform cancer prevention and control. Cancer Causes Control 2010;21:649-656.

376 Hansen KD, Timp W, Bravo HC, et al. Increased methylation variation in epigenetic domains across cancer types. Nat Genet 2011;43:768-775.

377 Berman BP, Weisenberger DJ, Aman JF, et al. Regions of focal DNA hypermethylation and long-range hypomethylation in colorectal cancer coincide with nuclear lamina-associated domains. Nat Genet 2012;44:40-46.

$378 \mathrm{Xu} \mathrm{Y}, \mathrm{Hu} \mathrm{B}$, Choi AJ, et al. Unique DNA methylome profiles in $\mathrm{CpG}$ island methylator phenotype colon cancers. Genome Res 2012;22:283-291.

379 Spitz MR, Caporaso NE, Sellers TA. Integrative cancer epidemiology - the next generation. Cancer Discovery 2012;2:1087-1090. 